University of Nebraska - Lincoln

DigitalCommons@University of Nebraska - Lincoln

Publications from USDA-ARS / UNL Faculty

U.S. Department of Agriculture: Agricultural

Research Service, Lincoln, Nebraska

2008

\title{
EPIC Evaluation of the Impact of Poultry Litter Application Timing on Nutrient Losses
}

\author{
H. Allen Torbert \\ United States Department of Agriculture \\ Thomas J. Gerik \\ Blackland Research and Extension Center \\ Wyatte L. Harman \\ Blackland Research and Extension Center \\ Jimmy R. Williams \\ Blackland Research and Extension Center \\ Melanie Magre \\ Blackland Research and Extension Center
}

Follow this and additional works at: https://digitalcommons.unl.edu/usdaarsfacpub

Part of the Agricultural Science Commons

Torbert, H. Allen; Gerik, Thomas J.; Harman, Wyatte L.; Williams, Jimmy R.; and Magre, Melanie, "EPIC Evaluation of the Impact of Poultry Litter Application Timing on Nutrient Losses" (2008). Publications from USDA-ARS / UNL Faculty. 598.

https://digitalcommons.unl.edu/usdaarsfacpub/598

This Article is brought to you for free and open access by the U.S. Department of Agriculture: Agricultural Research Service, Lincoln, Nebraska at DigitalCommons@University of Nebraska - Lincoln. It has been accepted for inclusion in Publications from USDA-ARS / UNL Faculty by an authorized administrator of DigitalCommons@University of Nebraska - Lincoln. 


\title{
EPIC Evaluation of the Impact of Poultry Litter Application Timing on Nutrient Losses
}

\author{
H. Allen Torbert, ${ }^{1}$ Thomas J. Gerik, ${ }^{2}$ Wyatte L. Harman, ${ }^{2}$ \\ Jimmy R. Williams, ${ }^{2}$ and Melanie Magre ${ }^{2}$ \\ ${ }^{1}$ United States Department of Agriculture, Agricultural Research Service, \\ National Soil Dynamics Laboratory, Auburn, Alabama, USA \\ ${ }^{2}$ Blackland Research and Extension Center, Temple, Texas, USA
}

\begin{abstract}
Recently, changes in the utilization practices of animal manures for fertilization have been encouraged to reduce the potential of nonpoint pollution of lakes and streams from agricultural land. However, the potential impact of changing some of these practices has not been fully studied. The objective of this study was to examine the potential impact of limiting poultry litter application times on nutrient movement important to water quality. The WinEPIC model was used to simulate poultry litter applications during the winter months and chemical fertilizer application, with both cool season and warm season grass pastures on the major soil regions of Alabama. With the warm season grass, soluble nitrogen $(\mathrm{N})$ losses could be reduced if the application of poultry litter was made after 30 December. With the cool season grasses, there was no significant difference in application dates for poultry litter for soluble $\mathrm{N}$ losses for any soil region, and no improvement could be noted for limiting applications in northern Alabama compared to southern Alabama. No significant difference was observed for soluble phosphorus (P) losses for application date for either warm season or cool season grass pastures. This indicates that factors other than plant $\mathrm{P}$ uptake during the growing season were the dominant regulators of the amount of soluble $\mathrm{P}$ lost in runoff. Also, the results would indicate that best management practices such as are administered with the $\mathrm{P}$ index are more important than plant growth factors in determining $\mathrm{N}$ and $\mathrm{P}$ losses to the environment.
\end{abstract}

Keywords: EPIC model, nitrogen, phosphorus, poultry litter, runoff water quality

Received 26 April 2007; Accepted 8 September 2007

Address correspondence to H. Allen Torbert, USDA-ARS, National Soil Dynamics Laboratory, 411 S. Donahue Drive, Auburn, AL 36832-5806. 


\section{INTRODUCTION}

Manure collected from confined broiler feeding operations has traditionally been applied to fields near the operation as a practical means of improving soil physical properties and economically enhancing soilavailable nutrients for crop production. However, the highest potential of phosphorus $(\mathrm{P})$ contribution to surface waters in watersheds is also from such nonpoint sources as the surface application of manures from intensive animal production (Kellogg and Lander 1999; McFarland and Hauck 1999; Sims et al. 2000). Nonpoint source pollution from agriculture has been identified as the leading source of water-quality reduction by the U.S. Environmental Protection Agency (USEPA) (Parry 1998). Poor fertilization practices (both inorganic and organic) can lead to excessive runoff, leaching of nutrients, and nonpoint pollution of lakes and streams from agricultural land. Although these impairments are not specific, both nitrogen $(\mathrm{N})$ and $\mathrm{P}$ have been implicated in accelerated eutrophication. The role of nutrients in the eutrophication process is very complex, but in general, freshwater eutrophication is associated with $\mathrm{P}$, whereas $\mathrm{N}$ is associated with ocean waters, and both $\mathrm{N}$ and $\mathrm{P}$ are associated with estuaries (Correll 1998; Daniel, Sharpley, and Lemunyon 1998).

Changes in the way that animal manures are utilized for fertilization have been encouraged as our knowledge of the best methods to potentially reduce nonpoint pollution of lakes and streams grows, especially in areas of intensive animal production such as in Alabama. To address the potential enrichment of surface waters from land application of manure, the USDA and USEPA developed a joint strategy for sustainable nutrient management (USDA and USEPA 1999). As a result, new policies and standards for nutrient management were adopted by the Alabama Natural Resource Conservation Service (NRCS) in May 2001. One important aspect to broiler producers was the new standard for manure application timing, which stated: "Animal manures, related organic by-products, or wastewater will not be applied in the fall or winter unless applied to an actively growing crop making sufficient growth to utilize the nutrients that are applied. Cold temperature and reduced photoperiod contribute to a severe reduction and, in most cases, a halt of significant growth and production of dry mass crucial to nutrient uptake. In North Alabama (see Figure 1) from approximately November 15 and February 15, apply no more than 30 pounds of nitrogen per acre to the crops" (USDANRCS, AL code 590, January 2001). This standard effectively bans the application of animal manures in north Alabama during the 15 November to 15 February period. In Alabama, broiler chickens represent the largest intensive animal production system, accounting for more than $40 \%$ of the state's agriculture cash receipts ( $\$ 1.84$ billion) in 2003 , but they also produced 


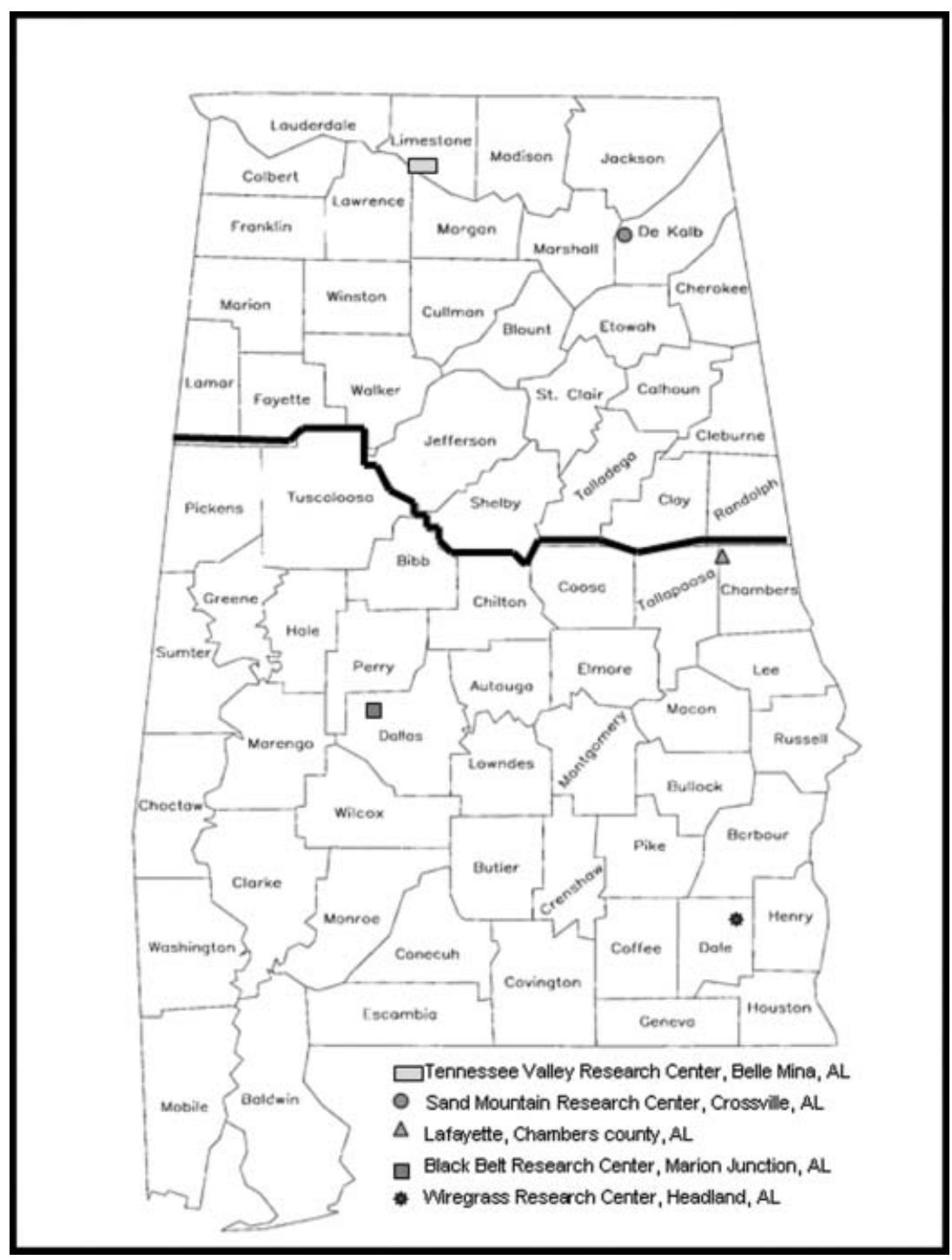

Figure 1. Map of the state of Alabama showing the location of the manure application ban and the sites for chosen for the typical soil type and weather station for each of these major soil regions of the state.

approximately 1.4 million tons of litter (Alabama Agricultural Statistics Bulletin 2004). The largest area affected by the poultry litter application ban is north Alabama, with its high concentration of broiler producers. Possible benefits of the manure application ban on reducing $\mathrm{N}$ and $\mathrm{P}$ losses from poultry litter applications have not been fully studied. 
Many interacting factors, both geographic soil conditions and temporal changes in weather conditions, are important to nutrient losses and water quality when animal manure (poultry litter) is applied. To adequately explore these potential differences in conditions, we used the simulation model WinEPIC [a Windows-based application of the Environmental/Policy Integrated Climate model (EPIC); Gerik et al. 2003], which is capable of evaluating cultural practices and cropping systems on production, soil quality, water quality, water and wind erosion, and profits. EPIC was originally developed by USDA-ARS to simulate the interaction of natural resources and crop management practices (Williams 1995).

The WinEPIC model has been demonstrated to predict nutrient losses with poultry litter applications reasonably well. Recently, Wang et al. (2006) evaluated EPIC for assessing nutrient losses from poultry litter fertilization. They concluded that the statistical test used in this assessment indicated that EPIC was able to replicate water-quality impacts of poultry litter application. The study site for this study was in the Blackland Prairie of Texas, which is closely related to the prairie soils of Alabama. In another example, using the EPIC model to study soil P accumulation in a tall fescue (Fescue arundinacea Schreb) pastures and cotton (Gossypium hirsutum L.) fields in paired field studies in which one field received poultry litter application from 18-20 years and the other received conventional N and P fertilization, Mullins and Hajek (1997) found that the model compared favorably with actual concentrations for both tall fescue and cotton. They concluded that the results supported the use of EPIC as a tool for planning best management practices (BMPs) for poultry litter application. In a separate study, Mullins and Hajek (1997) compared the results of the EPIC model to the results reported by Kingery et al. (1994) for a study in which they measured 20 years of application of poultry litter on 11 paired tall fescue pastures on a Hartsell sandy loam soil in the Appalachia Plataea of Alabama. They reported that EPIC simulations corresponded well with the measured active $P$ levels and could be used to predict the magnitude of soluble $\mathrm{P}$ and sediment $\mathrm{P}$ losses. In a water-quality monitoring project in Arkansas, Edwards et al. (1993) reported that the EPIC model gave a reasonable correlation $\left(\mathrm{r}^{2}=0.80\right)$ between the predicted levels of annual $\mathrm{P}$ losses compared to the observed levels for pastures that had received either inorganic fertilizer or poultry litter.

The WinEPIC model has recently been updated with the data sets for operation under Alabama conditions and was found to work well for cotton (Gossypium hirsutum L.), corn (Zea mays L.), and peanuts (Arachis hypogaea L.) when grown under typical conditions across the state of Alabama (Torbert et al. 2005).

The objective of this study was to examine the impact of limiting poultry litter application times on nutrient movement important to water quality. 
The computer model WinEPIC was used to simulate poultry litter application during the winter months (before, during, and after the manure application ban) and chemical fertilizer application, with both cool season and warm season grass pastures on the major soil regions of Alabama.

\section{MATERIALS AND METHODS}

\section{WinEPIC}

This study used WinEPIC to ascertain the potential impacts of the Alabama poultry litter ban on nutrient losses important to water quality. WinEPIC is a continuous, daily time-step simulation model that uses weather, hydrology, erosion-sedimentation, nutrient cycling, plant growth, soil temperature, tillage, and plant environment control to determine the effect of management strategies on agricultural production and soil and water resources. The drainage area considered for the WinEPIC simulations was a field-sized area of 125 ha. Weather, soils, and management systems for the entire field area are assumed to be homogeneous. In this study, 36 years of simulations were conducted with WinEPIC using historical weather data of Alabama for the simulated weather conditions.

\section{Soil and Weather}

Alabama is made up of five major agriecological regions (not including flood plain and coastal marsh regions), which include the Limestone Valley, Appalachian Plateau, Piedmont Plateau, Prairie, and Coastal Plains (Mitchell and Meetze 1990). The principal regions in the poultry litter ban area include the Limestone Valley, Appalachian Plateau, and parts of the Piedmont Plateau. Because of the concentration of the poultry industry (Alabama Agricultural Statistics Bulletin 2004), the soils of the Appalachian Plateau are a primary concern. For this study, a typical soil type and weather station were chosen from each of these major regions (Figure 1). The simulation used historic weather (40 years) collected from weather stations in each region.

In the Appalachian Plateau, a Wynnville fine sandy loam (fineloamy, siliceous, subactive, thermic Glossic Fragiudults) soil was chosen, and the weather station was at the Alabama Sand Mountain Research and Extension Center, Crossville, Ala. In the Limestone Valley, a Decatur silt loam (Fine, Kaolinitic, thermic Rhodic Paleudults) was chosen and the weather station was at the Alabama Tennessee Valley Research and Extension Center at Belle Mina, Ala. In the Piedmont 
Plateau, a Cecil clay loam (fine, kaolinitic, thermic Typic Kanhapludults) was selected, and the weather station was located in Lafayette, Ala. In the Coastal Plains, a Dothan loamy sand (fine-loamy, Kaolinitic, thermic Plinthic Kandiudults) was used, and the weather station chosen was at the Alabama Wiregrass Research and Extension Center at Headland, Ala. In the Prairies, a Houston clay (very-fine, smectitic, thermic Oxyaquic Hapluderts) was chosen, and the weather station was at the Alabama Black Belt Research and Extension Center, at Marion Junction, Ala.

The soil characteristics (except extractable P) for each chosen soil were obtained from the Soils-5 database, which was created and maintained by the USDA-Natural Resources Conservation Service (USDA NRCS 2005). Soil test $P$ was set for each soil at $56 \mathrm{~kg} \mathrm{ha}^{-1}$ extractable P. In Alabama, $56 \mathrm{~kg} \mathrm{ha}^{-1}\left(50 \mathrm{lb} \mathrm{acre}^{-1}\right)$ of extractable P is designated as a "high" soil $\mathrm{P}$ test rating for all soil types, except in the prairie soils, where it would be designated as a "medium" soil test $\mathrm{P}$ (Adams, Mitchell, and Bryant 1994).

Soil $\mathrm{P}$ buildup occurs when application of $\mathrm{P}$ to soil, generally through manure application, exceeds plant needs. Research has shown that soil $\mathrm{P}$ level is directly related to runoff losses of P (Pote et al. 1996; McDowell and Sharpley 2001; Torbert et al. 2002). However, the objective of this study was to evaluate the impact of the manure application, not the longterm impact of manure to soil $\mathrm{P}$ buildup (other aspects of the manure application regulations consider the impact of soil buildup of $\mathrm{P}$ ). The soil test was set to a high level because poultry litter is commonly applied to the same fields areas, which would likely result in a high soil-test P level. However, the simulations were conducted such that the soil-test level was reset to $56 \mathrm{~kg} \mathrm{ha}^{-1}$ extractable $\mathrm{P}$ after every 9 years of simulation so that the soil $\mathrm{P}$ levels did not overwhelm the impact of manure application. This allowed for a better comparison for the first years of the simulations to the last years of the simulations.

\section{Pastures}

To evaluate potential difference in plant growth characteristic during the poultry litter ban, three pasture plant species were chosen that are common throughout Alabama and routinely fertilized with poultry litter. Both a cool season perennial grass, tall fescue or orchardgrass (Dactylis glomerata), and a warm season perennial grass, bermudagrass (Cynodon dactylon), species were chosen to evaluate the impact of having an actively growing pasture species during the poultry litter ban period. The orchardgrass simulations were limited to the Tennessee Valley and the Appalachian Plateau, because it is not adaptable to the lower portions of 
Alabama (Ball, Hoveland, and Lacefield 2002). A small grain, rye (Secale cereale), was also simulated to evaluate the impact of a cool season annual growing during the poultry litter ban period.

\section{Poultry Litter Applications}

To evaluate potential differences in the timing of poultry litter application, five different poultry litter application times were chosen to compare before, during, and after the 15 November through 15 February ban period. The times chosen were 15 October (before ban period), 20 November (early in ban period), 30 December (middle of ban period), 10 February (end of ban period), and 1 March (after ban period). In addition, to compare the impact of poultry litter to commercial chemical fertilizer sources of $\mathrm{N}$ and $\mathrm{P}$, two application times for commercial fertilizer were also made. These application times were 15 October (before ban period) and 1 March (after ban period).

The application of poultry litter was made at a rate of $9 \mathrm{Mg} \mathrm{ha}^{-1}$, the recommended single application rate limit for poultry litter application to pastures in Alabama (Edminsten et al. 1992). In Alabama, the average fertilizer grade for poultry litter is equivalent to 3-3-2 (Edminsten et al. 1992). Therefore, the simulation model was set to apply poultry litter, which would contain $269 \mathrm{~kg} \mathrm{Nha}^{-1}$ and $118 \mathrm{~kg} \mathrm{Pha}^{-1}$, at the designated times. The forms of the $\mathrm{N}$ and $\mathrm{P}$ in the poultry litter were also established at levels reported in Alabama (Edminsten et al. 1992). The $\mathrm{N}$ in the poultry litter was set to contain $33.3 \%$ in the inorganic $\mathrm{N}$ form $(85 \%$ ammonium form and $15 \%$ nitrate form). The remaining $66.6 \%$ was in the organic $\mathrm{N}$ form. Phosphorous was set to contain $25 \%$ soluble P, $10 \%$ of which was soluble organic $\mathrm{P}$. The remaining $75 \%$ was in the organic form (not soluble).

For commercial fertilizer application, $\mathrm{N}$ was applied as ammonium nitrate at a rate of $269 \mathrm{~kg} \mathrm{ha}^{-1}$. However, because the application of $\mathrm{P}$ in poultry litter is much higher than would be recommended with commercial fertilizer, application of chemical $\mathrm{P}$ was made at a rate $67 \mathrm{~kg} \mathrm{ha}^{-1}$, which is at the high end of fertilizer $\mathrm{P}$ recommendation rates for Alabama, even with very low soil-test P levels (Adams, Mitchell, and Bryant 1994).

Statistical analyses of simulation results were performed using procedures of SAS (SAS Institute 1982). Replication in this study was provided by averaging over each of the 9 year study periods of historical weather conditions for a total of four replications for comparison between treatments. Means were separated using Duncan's at an a priori 0.01 probability level. To show the range of losses relative to all weather 
conditions observed over the 36 years of the study, cumulative probabilities of losses of soluble $\mathrm{N}$ and $\mathrm{P}$ at each application date and for both the poultry litter and the chemical fertilizer treatments were also generated.

\section{RESULTS AND DISCUSSION}

\section{Yield and Plant $P$ and N Uptake}

The results from the WinEpic simulations for average annual pasture forage yields and plant uptake of $\mathrm{N}$ and $\mathrm{P}$ are shown in Tables 1, 2, and 3. Differences can be seen between the yield levels of the different pasture species and soil type region, which fall within the general range expected for these pasture species in Alabama (Ball, Hoveland, and Lacefield 2002). The highest forage yield levels were observed in the bermudagrass (the warm season grass species) within each soil type. In the northern soil type regions (Appalachia Plateau and Limestone Valley), the rye had higher yields compared to the perennial cool season grass species. Also in these northern regions, because of their similar growth characteristics, little difference was observed between cool season grasses (orchardgrass and tall fescue). Likewise, uptake of $\mathrm{N}$ and $\mathrm{P}$ were in the range expected for each of the plant species, and differences closely followed those observed for yield (Tables 2 and 3 ).

Differences in forage yield were observed between poultry litter and chemical fertilizer applications (Table 1), with an increase in forage yields generally observed for the most part with the chemical fertilizer application for all pasture species and all soil types. This difference was most pronounced with bermudagrass (with its higher yield potential), with as much as $7.4 \mathrm{tha}^{-1}$ increase in forage yield with the Coastal Plain soil. This difference was likely due to $\mathrm{N}$ stress during the growing season due to limitations of plant-available N. Because poultry litter has two thirds of its $\mathrm{N}$ in the organic $\mathrm{N}$ form, which is not available for plant uptake, decomposition of the poultry litter must occur before a large portion of the $\mathrm{N}$ supplied with the poultry litter becomes available to the plant. Differences were most pronounced in the Piedmont Plateau and Coastal Plains soil types for bermudagrass, and in tall fescue at the Appalachia Plateau and Limestone Valley, where the yield potentials for these pasture species are highest. This is consistent with the results observed with nutrient uptake, with much higher $\mathrm{N}$ content in the plants with higher yields (Table 2). Differences observed were smallest in the prairie soil, with no difference observed for rye. This was likely due to the inherent fertility of the prairie soil to provide adequate nutrients. 
Table 1. Effect of application date of poultry litter $\left(\mathrm{tha}^{-1}\right)$ and chemical fertilizer $\left(\mathrm{tha}^{-1}\right)$ on pasture yield (tha $\left.{ }^{-1}\right)$ for the Appalachia Plateau, Limestone Valley, Coastal Plains, Prairie, and Piedmont Plateau soil region ${ }^{a}$

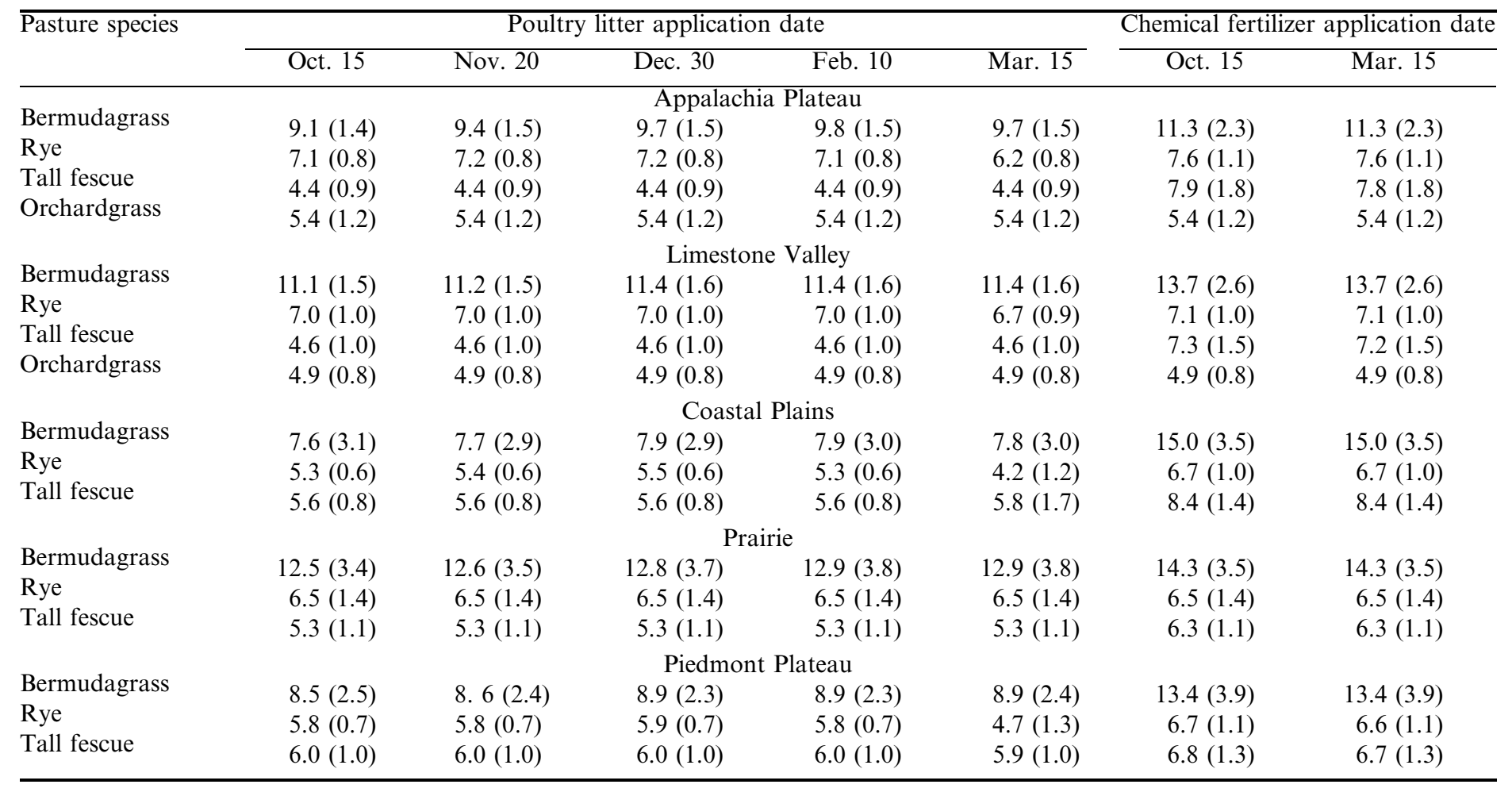

${ }^{a}$ Values represent means of 36 -year simulations. 
Table 2. Effect of application date of poultry litter and chemical fertilizer on pasture plant $\mathrm{N}$ uptake $\mathrm{kg} \mathrm{N}^{-1}$ for the Appalachia Plateau, Limestone Valley, Coastal Plains, Prairie, and Piedmont Plateau soil region ${ }^{a}$

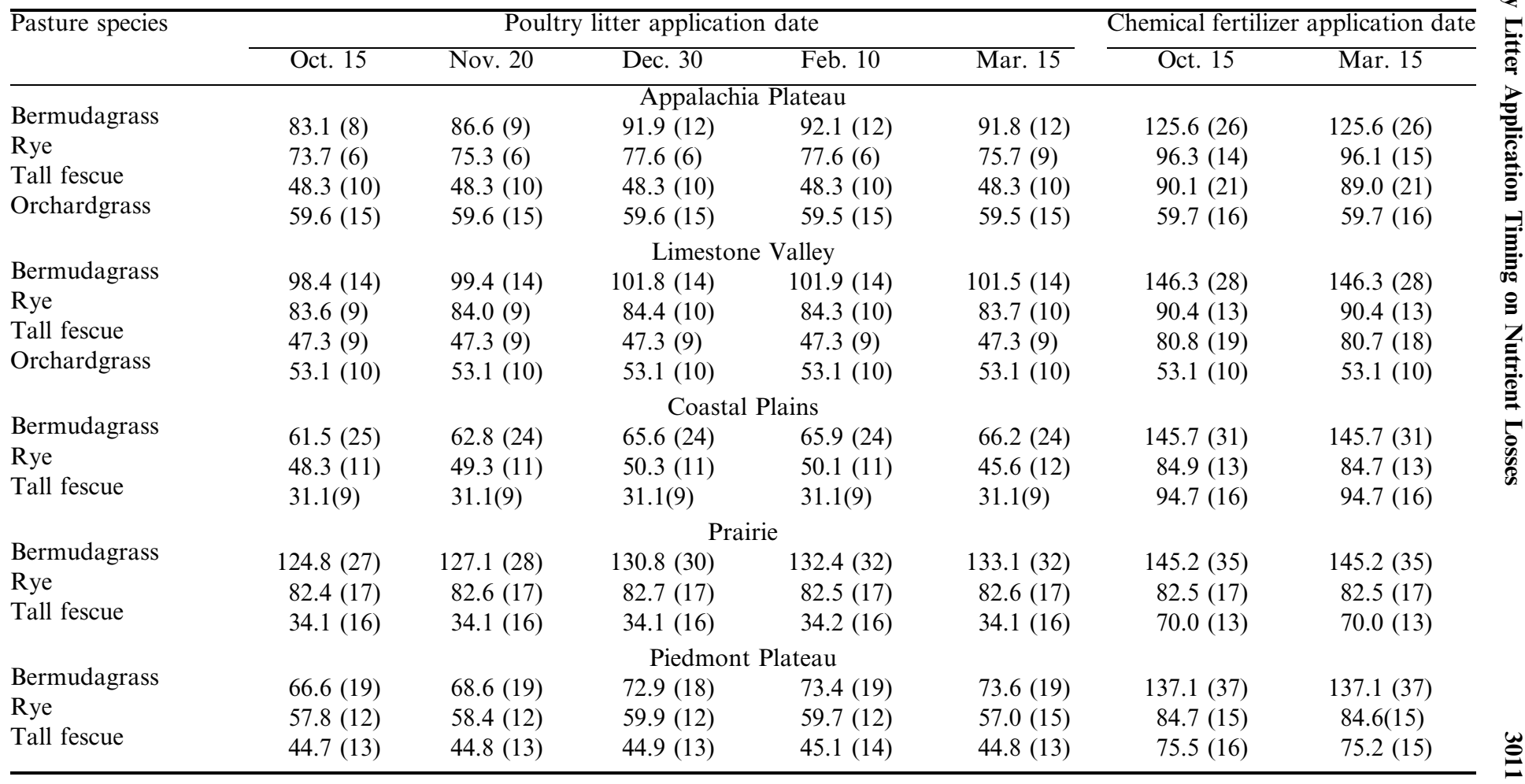

${ }^{a}$ Values represent means of 36 -year simulations. 
Table 3. Effect of application date of poultry litter and chemical fertilizer on pasture plant $\mathrm{P}$ uptake $\mathrm{kg} \mathrm{Pha}^{-1}$ for the Appalachia Plateau, Limestone Valley, Coastal Plains, Prairie, and Piedmont Plateau soil region ${ }^{a}$

\begin{tabular}{|c|c|c|c|c|c|c|c|}
\hline \multirow[t]{2}{*}{$\begin{array}{l}\text { Pasture } \\
\text { species }\end{array}$} & \multicolumn{5}{|c|}{ Poultry litter application date } & \multicolumn{2}{|c|}{$\begin{array}{l}\text { Chemical fertilizer } \\
\text { application date }\end{array}$} \\
\hline & Oct. 15 & Nov. 20 & Dec. 30 & Feb. 10 & Mar. 15 & Oct. 15 & Mar. 15 \\
\hline \multicolumn{8}{|c|}{ Appalachia Plateau } \\
\hline Bermudagrass & $16.6(2)$ & $17.0(2)$ & $17.7(3)$ & $17.7(3)$ & $17.7(3)$ & $21.0(4)$ & $21.0(4)$ \\
\hline Rye & $10.8(1)$ & $11.0(1)$ & $11.0(1)$ & $11.0(1)$ & $9.5(1)$ & $11.6(2)$ & $11.6(2)$ \\
\hline Tall fescue & $8.9(2)$ & $8.9(2)$ & $8.9(2)$ & $9.0(2)$ & $9.0(2)$ & $16.6(4)$ & $16.5(4)$ \\
\hline Orchardgrass & $11.0(3)$ & $11.0(3)$ & $11.0(3)$ & $11.0(3)$ & $11.0(3)$ & $11.0(3)$ & $11.1(3)$ \\
\hline \multicolumn{8}{|c|}{ Limestone Valley } \\
\hline Bermudagrass & $19.4(2)$ & $19.6(2)$ & $20.0(2)$ & $20.0(2)$ & $20.0(2)$ & $24.5(5)$ & $24.5(5)$ \\
\hline Rye & $10.7(2)$ & $10.7(2)$ & $10.7(2)$ & $10.7(2)$ & $10.3(1)$ & $10.9(2)$ & $10.9(2)$ \\
\hline Tall fescue & $8.8(2)$ & $8.8(2)$ & $8.8(2)$ & $8.8(2)$ & $8.8(2)$ & $14.9(3)$ & $14.9(3)$ \\
\hline Orchardgrass & $9.8(2)$ & $9.8(2)$ & $9.8(2)$ & $9.8(2)$ & $9.8(2)$ & $9.8(2)$ & $9.8(2)$ \\
\hline \multicolumn{8}{|c|}{ Coastal Plains } \\
\hline Bermudagrass & $14.2(4)$ & $14.4(4)$ & 14.7 (4) & $14.7(4)$ & $14.7(4)$ & $24.6(5)$ & $24.6(5)$ \\
\hline Rye & $8.0(1)$ & $8.2(1)$ & $8.3(1)$ & $8.1(1)$ & $6.4(2)$ & $10.2(2)$ & $10.2(2)$ \\
\hline Tall fescue & $5.821)$ & $5.8(2)$ & $5.9(2)$ & $5.9(2)$ & $5.8(2)$ & $17.4(3)$ & $17.4(3)$ \\
\hline \multicolumn{8}{|c|}{ Prairie } \\
\hline Bermudagrass & $21.8(5)$ & $22.0(5)$ & $22.3(5)$ & $22.4(6)$ & $22.5(6)$ & $24.4(6)$ & $24.6(5)$ \\
\hline Rye & $9.9(2)$ & $9.9(2)$ & $9.9(2)$ & $9.9(2)$ & $9.9(2)$ & $9.9(2)$ & $9.9(2)$ \\
\hline Tall fescue & $6.3(3)$ & $6.3(3)$ & $6.3(3)$ & $6.3(3)$ & $6.3(3)$ & $12.9(2)$ & $12.9(2)$ \\
\hline \multicolumn{8}{|c|}{ Piedmont Plateau } \\
\hline Bermudagrass & $15.1(4)$ & $15.2(4)$ & $15.7(4)$ & $15.7(4)$ & $15.7(4)$ & $23.0(6)$ & $23.0(6)$ \\
\hline Rye & $8.8(1)$ & $8.9(1)$ & $9.0(1)$ & $8.8(1)$ & $7.2(2)$ & $10.2(2)$ & $10.2(2)$ \\
\hline Tall fescue & $8.4(2)$ & $8.4(2)$ & $8.5(2)$ & $8.5(2)$ & $8.4(2)$ & $14.3(4)$ & $15.7(4)$ \\
\hline
\end{tabular}

${ }^{a}$ Values represent means of 36 -year simulations.

Surprisingly, little difference could be observed between the application dates for forage yield, both among poultry litter application dates and chemical fertilizer applications dates (Table 1). This was true for all soil types, regardless of whether the soil region was found above or below the poultry litter ban area. With rye, a drop in yield could be observed with the 15 March application of poultry litter compared to the other application dates, except in the prairie soil (Table 1). This included soil types that are found in the poultry litter application ban area. This was likely due to $\mathrm{N}$ limitations resulting from poultry litter having insufficient time to decompose to supply $\mathrm{N}$ before the peak growth period of rye. This corresponded with data observed for $\mathrm{N}$ uptake in rye (Table 2), which had lower $\mathrm{N}$ content when poultry litter was applied on 
15 March compared to other application dates. This would be consistent with $\mathrm{N}$ being a limiting factor for rye growth for application of poultry litter at this time. In the prairie soil type, no drop in yield was observed, likely because of the inherent soil fertility of this soil.

With warm season bermudagrass, poultry litter application dates impacted the level of $\mathrm{N}$ uptake in the plant (Table 2), with the plant $\mathrm{N}$ uptake increased by waiting until spring to apply the litter. This was likely due to $\mathrm{N}$ losses during the winter months resulting in reduced $\mathrm{N}$ uptake during the year. These losses occurred in both the north and south Alabama soil areas (Table 2).

With the cool season grasses, results for plant $\mathrm{N}$ uptake show no difference between the poultry litter application dates, with the exception of the lower $\mathrm{N}$ uptake observed with rye for application on 15 March (Table 2). Similarly, there was only a slight difference between $\mathrm{N}$ uptake for the chemical fertilizer applied before and after the ban period. With the cool season grasses, there was no indication that plant $\mathrm{N}$ uptake of nutrients was positively impacted by application of the poultry litter during the time of actively growing plants, for both soil types within and outside the ban area. This was consistent with findings of Sørensen and Thomsen (2005) examining the dry-matter-rich fraction of pig manure applied either in autumn or in spring to winter wheat. Using ${ }^{15} \mathrm{~N}$-labeled techniques, they found that the same amount of $\mathrm{N}$ in the manure was lost irrespective of whether it was applied in autumn or in spring.

Uptake of $\mathrm{P}$ in plants was impacted by application times and type of fertilizer, which primarily corresponded to yield response (Table 3). A large difference could be noted for uptake of $\mathrm{P}$ in the plants that received chemical fertilizer compared to those that received poultry litter. However, this is likely a response to the positive yield observed with chemical fertilizer resulting in improved plant P uptake. It is not likely that this was a result of $\mathrm{P}$ availability limitation, because much more total $\mathrm{P}$ was applied with the poultry litter.

With the cool season grasses, only small differences were observed between application dates for plant $\mathrm{P}$ uptake (Table 3). There was no advantage in applying poultry litter after the litter ban as compared to during the poultry litter application ban for $\mathrm{P}$ uptake in the plant. The exception was for tall fescue in the Appalachia Plateau, where application in February and March was slightly improved compared to application on the October, November, and December dates. However, in several cases, it can be observed that application on 15 March reduced plant $\mathrm{P}$ uptake compared to application during the poultry litter application ban, which corresponded to yield reductions at these same times. With the warm season bermudagrass, a positive response to plant $\mathrm{P}$ uptake can be noted with applications made nearer to the growing season, which again corresponds to observed plant yield. However, in no case was there an 
increased level of $\mathrm{P}$ uptake with the application of poultry litter on 15 March compared to application of poultry litter during the ban.

\section{Nutrient Losses}

The 36-year average losses of soluble $\mathrm{N}$ and $\mathrm{P}$, organic $\mathrm{N}$ and $\mathrm{P}$, and percolate $\mathrm{N}$ and $\mathrm{P}$ for each of the pasture species at each of the soil locations are shown in Tables 4-8. The range of losses relative to all weather conditions observed over the 36 years of the study and cumulative probabilities are shown in Figures 2-7. These figures show the cumulative probability of losses of soluble $\mathrm{N}$ and $\mathrm{P}$ at each application date for both the poultry litter and the chemical fertilizer treatments and provide a graphical depiction of the variability of the nutrient losses over the range of experimental conditions and the relative differences between the treatments.

\section{Nitrogen}

The average loss for the 36 years of soluble $\mathrm{N}$ in the runoff was very small relative to the application rate for all of the pasture species at all of the soil locations, with a range of 0.6 to $0.019 \mathrm{~kg} \mathrm{ha}^{-1}$. These very small losses relative to the amount applied can also be observed in the probability percentage of soluble losses of $\mathrm{N}$, which shows the full range of simulated soluble $\mathrm{N}$ losses observed in this study (Figures 2, 3, and 4). The highest annual loss observed for soluble $\mathrm{N}$ was $1 \mathrm{~kg} \mathrm{ha}^{-1}$ at the Piedmont soil location, which is only $0.83 \%$ of the $\mathrm{N}$ applied each year. Losses of less than $1 \%$ of the applied $\mathrm{N}$ would have no agronomic impact.

Although the level of losses were small, differences could be observed between the application treatments. By far, the largest impact was the difference between the chemical fertilizer applications and the poultry litter application treatments. Large increases in the average annual losses of soluble $\mathrm{N}$ with the application of chemical fertilizer were observed compared to the poultry litter applications, whether applied within or outside of the ban period (Tables 4-8). Similarly, large increases in the level of percolate $\mathrm{N}$ were observed with the application of chemical fertilizer compared to the poultry litter application (Tables 4-8). These differences with chemical fertilizer compared to poultry litter were significant at all locations and with all grasses. This difference was most likely because in the case of the chemical fertilizer application of $\mathrm{N}$, all of the added $\mathrm{N}$ is in the inorganic form, which can be easily mobilized with water moving across the soil surface. In the case of poultry litter, most of the $\mathrm{N}$ is in the organic form, which is not easily transmitted with surface 
Table 4. Effect of application date on $\mathrm{N}$ and $\mathrm{P}$ losses $\left(\mathrm{kgha}^{-1}\right)$ for the Appalachia Plateau soil region ${ }^{a}$

\begin{tabular}{|c|c|c|c|c|c|c|}
\hline $\begin{array}{l}\text { Fertilizer application } \\
\text { date }^{b}\end{array}$ & $\begin{array}{l}\text { Soluble } \\
\mathrm{N}\end{array}$ & $\begin{array}{l}\text { Soluble } \\
\text { P }\end{array}$ & $\begin{array}{l}\text { Organic } \\
\mathrm{N}\end{array}$ & $\begin{array}{l}\text { Organic } \\
\mathrm{P}\end{array}$ & $\begin{array}{l}\text { Percolate } \\
\text { N }\end{array}$ & $\begin{array}{c}\text { Percolate } \\
\text { P }\end{array}$ \\
\hline \multicolumn{7}{|c|}{ Bermudagrass } \\
\hline Inorg. Oct.15 & $0.531 \mathrm{a}$ & $0.017 \mathrm{a}$ & $0.102 \mathrm{a}$ & $0.010 \mathrm{~b}$ & $10.650 \mathrm{a}$ & $0.114 \mathrm{a}$ \\
\hline Inorg. Mar.15 & $0.426 \mathrm{~b}$ & $0.013 \mathrm{a}$ & $0.102 \mathrm{a}$ & $0.010 \mathrm{~b}$ & $9.570 \mathrm{a}$ & $0.114 \mathrm{a}$ \\
\hline PL Oct. 15 & $0.088 \mathrm{c}$ & $0.019 \mathrm{a}$ & $0.138 \mathrm{a}$ & $0.037 \mathrm{a}$ & $0.799 \mathrm{~b}$ & $0.114 \mathrm{a}$ \\
\hline PL Nov.20 & $0.077 \mathrm{~cd}$ & $0.019 \mathrm{a}$ & $0.134 \mathrm{a}$ & $0.037 \mathrm{a}$ & $0.586 \mathrm{~b}$ & $0.114 \mathrm{a}$ \\
\hline PL Dec. 30 & $0.050 \mathrm{de}$ & $0.019 \mathrm{a}$ & $0.130 \mathrm{a}$ & $0.036 \mathrm{a}$ & $0.396 \mathrm{~b}$ & $0.115 \mathrm{a}$ \\
\hline PL Feb. 10 & $0.045 \mathrm{e}$ & $0.016 \mathrm{a}$ & $0.128 \mathrm{a}$ & $0.031 \mathrm{a}$ & $0.386 \mathrm{~b}$ & $0.115 \mathrm{a}$ \\
\hline PL Mar. 15 & $0.039 \mathrm{e}$ & $0.016 \mathrm{a}$ & $0.128 \mathrm{a}$ & $0.031 \mathrm{a}$ & $0.384 \mathrm{~b}$ & $0.115 \mathrm{a}$ \\
\hline \multicolumn{7}{|c|}{ Tall fescue } \\
\hline Inorg. Oct. 15 & $0.468 \mathrm{a}$ & $0.009 \mathrm{ab}$ & $0.222 \mathrm{a}$ & $0.031 \mathrm{~b}$ & $10.516 \mathrm{a}$ & $0.045 \mathrm{a}$ \\
\hline Inorg. Mar. 15 & $0.468 \mathrm{a}$ & $0.006 \mathrm{~b}$ & $0.220 \mathrm{a}$ & $0.030 \mathrm{~b}$ & $9.216 \mathrm{a}$ & $0.045 \mathrm{a}$ \\
\hline PL Oct. 15 & $0.115 \mathrm{~b}$ & $0.016 \mathrm{a}$ & $0.248 \mathrm{a}$ & $0.069 \mathrm{a}$ & $2.846 \mathrm{~b}$ & $0.058 \mathrm{a}$ \\
\hline PL Nov. 20 & $0.103 \mathrm{~b}$ & $0.016 \mathrm{a}$ & $0.248 \mathrm{a}$ & $0.070 \mathrm{a}$ & $2.847 \mathrm{~b}$ & $0.058 \mathrm{a}$ \\
\hline PL Dec. 30 & $0.076 \mathrm{~b}$ & $0.015 \mathrm{a}$ & $0.249 \mathrm{a}$ & $0.069 \mathrm{a}$ & $3.071 \mathrm{~b}$ & $0.058 \mathrm{a}$ \\
\hline PL Feb. 10 & $0.086 \mathrm{~b}$ & $0.012 \mathrm{ab}$ & $0.240 \mathrm{a}$ & $0.059 \mathrm{ab}$ & $3.034 \mathrm{~b}$ & $0.058 \mathrm{a}$ \\
\hline PL Mar. 15 & $0.103 \mathrm{~b}$ & $0.012 \mathrm{ab}$ & $0.240 \mathrm{a}$ & $0.059 \mathrm{ab}$ & $2.944 \mathrm{~b}$ & $0.058 \mathrm{a}$ \\
\hline \multicolumn{7}{|c|}{ Orchardgrass } \\
\hline Inorg. Oct. 15 & $0.525 \mathrm{a}$ & $0.013 \mathrm{a}$ & $0.208 \mathrm{a}$ & $0.028 \mathrm{~b}$ & $14.124 \mathrm{a}$ & $0.055 \mathrm{a}$ \\
\hline Inorg. Mar. 15 & $0.523 \mathrm{a}$ & $0.010 \mathrm{a}$ & $0.208 \mathrm{a}$ & $0.028 \mathrm{~b}$ & $13.016 \mathrm{a}$ & $0.055 \mathrm{a}$ \\
\hline PL Oct. 15 & $0.138 \mathrm{~b}$ & $0.020 \mathrm{a}$ & $0.229 \mathrm{a}$ & $0.063 \mathrm{a}$ & $2.070 \mathrm{~b}$ & $0.053 \mathrm{a}$ \\
\hline PL Nov. 20 & $0.122 \mathrm{~b}$ & $0.020 \mathrm{a}$ & $0.230 \mathrm{a}$ & $0.063 \mathrm{a}$ & $2.088 \mathrm{~b}$ & $0.053 \mathrm{a}$ \\
\hline PL Dec. 30 & $0.092 \mathrm{~b}$ & $0.019 \mathrm{a}$ & $0.230 \mathrm{a}$ & $0.063 \mathrm{a}$ & $2.323 \mathrm{~b}$ & $0.053 \mathrm{a}$ \\
\hline PL Feb. 10 & $0.093 \mathrm{~b}$ & $0.015 \mathrm{a}$ & $0.225 \mathrm{a}$ & $0.052 \mathrm{ab}$ & $2.275 \mathrm{~b}$ & $0.053 \mathrm{a}$ \\
\hline PL Mar. 15 & $0.095 \mathrm{~b}$ & $0.015 \mathrm{a}$ & $0.224 \mathrm{a}$ & $0.052 \mathrm{ab}$ & $2.243 \mathrm{~b}$ & $0.053 \mathrm{a}$ \\
\hline \multicolumn{7}{|c|}{ Rye } \\
\hline Inorg. Oct. 15 & $0.498 \mathrm{a}$ & $0.056 \mathrm{a}$ & $0.247 \mathrm{a}$ & $0.049 \mathrm{a}$ & $12.721 \mathrm{a}$ & $0.169 \mathrm{a}$ \\
\hline Inorg. Mar. 15 & $0.513 \mathrm{a}$ & $0.057 \mathrm{a}$ & $0.248 \mathrm{a}$ & $0.050 \mathrm{a}$ & $11.656 \mathrm{a}$ & $0.169 \mathrm{a}$ \\
\hline PL Oct. 15 & $0.084 \mathrm{~b}$ & $0.075 \mathrm{a}$ & $0.342 \mathrm{a}$ & $0.182 \mathrm{a}$ & $0.601 \mathrm{~b}$ & $0.166 \mathrm{a}$ \\
\hline PL Nov. 20 & $0.071 \mathrm{bc}$ & $0.075 \mathrm{a}$ & $0.341 \mathrm{a}$ & $0.181 \mathrm{a}$ & $0.559 \mathrm{~b}$ & $0.166 \mathrm{a}$ \\
\hline PL Dec. 30 & $0.038 \mathrm{c}$ & $0.075 \mathrm{a}$ & $0.341 \mathrm{a}$ & $0.181 \mathrm{a}$ & $0.562 \mathrm{~b}$ & $0.166 \mathrm{a}$ \\
\hline PL Feb. 10 & $0.033 \mathrm{c}$ & $0.075 \mathrm{a}$ & $0.341 \mathrm{a}$ & $0.180 \mathrm{a}$ & $0.550 \mathrm{~b}$ & $0.167 \mathrm{a}$ \\
\hline PL Mar. 15 & $0.041 \mathrm{c}$ & $0.075 \mathrm{a}$ & $0.355 \mathrm{a}$ & $0.190 \mathrm{a}$ & $0.663 \mathrm{~b}$ & $0.182 \mathrm{a}$ \\
\hline
\end{tabular}

${ }^{a}$ Values represent means of 36-year simulations. Means within a column followed by the same letter do not differ significantly in Duncan's grouping ( $\alpha=$ $0.01)$.

${ }^{b}$ Inorg., inorganic fertilizer; PL, poultry litter.

runoff except in the sediment with erosional losses. The poultry litter has to be decomposed into inorganic $\mathrm{N}$ forms before it is susceptible to surface water runoff and leaching losses. Because the microbial activity is 
Table 5. Effect of application date on $\mathrm{N}$ and $\mathrm{P}$ losses $\left(\mathrm{kgha}^{-1}\right)$ for the Limestone Valley soil region $^{a}$

\begin{tabular}{|c|c|c|c|c|c|c|}
\hline $\begin{array}{l}\text { Fertilizer application } \\
\text { date }\end{array}$ & $\begin{array}{l}\text { Soluble } \\
\text { N }\end{array}$ & $\begin{array}{l}\text { Soluble } \\
\text { P }\end{array}$ & $\begin{array}{l}\text { Organic } \\
\qquad \mathrm{N}\end{array}$ & $\begin{array}{l}\text { Organic } \\
\text { P }\end{array}$ & $\begin{array}{c}\text { Percolate } \\
\text { N }\end{array}$ & $\begin{array}{c}\text { Percolate } \\
\text { P }\end{array}$ \\
\hline \multicolumn{7}{|c|}{ Bermudagrass } \\
\hline Inorg. Oct. $15^{b}$ & $0.552 \mathrm{a}$ & $0.016 \mathrm{a}$ & $0.138 \mathrm{a}$ & $0.019 \mathrm{~b}$ & $5.989 \mathrm{a}$ & $0.063 \mathrm{a}$ \\
\hline Inorg. Mar. 15 & $0.406 \mathrm{~b}$ & $0.012 \mathrm{a}$ & $0.138 \mathrm{a}$ & $0.018 \mathrm{~b}$ & $4.911 \mathrm{a}$ & $0.063 \mathrm{a}$ \\
\hline PL Oct. 15 & $0.095 \mathrm{c}$ & $0.018 \mathrm{a}$ & $0.179 \mathrm{a}$ & $0.048 \mathrm{a}$ & $0.306 \mathrm{~b}$ & $0.060 \mathrm{a}$ \\
\hline PL Nov. 20 & $0.083 \mathrm{c}$ & $0.018 \mathrm{a}$ & $0.177 \mathrm{a}$ & $0.048 \mathrm{a}$ & $0.259 \mathrm{~b}$ & $0.060 \mathrm{a}$ \\
\hline PL Dec. 30 & $0.044 \mathrm{~d}$ & $0.018 \mathrm{a}$ & $0.174 \mathrm{a}$ & $0.046 \mathrm{a}$ & $0.230 \mathrm{~b}$ & $0.060 \mathrm{a}$ \\
\hline PL Feb. 10 & $0.035 \mathrm{~d}$ & $0.015 \mathrm{a}$ & $0.169 \mathrm{a}$ & $0.040 \mathrm{a}$ & $0.229 \mathrm{~b}$ & $0.061 \mathrm{a}$ \\
\hline PL Mar. 15 & $0.028 \mathrm{~d}$ & $0.015 \mathrm{a}$ & $0.169 \mathrm{a}$ & $0.040 \mathrm{a}$ & $0.226 \mathrm{~b}$ & $0.061 \mathrm{a}$ \\
\hline \multicolumn{7}{|c|}{ Tall fescue } \\
\hline Inorg. Oct. 15 & $0.518 \mathrm{a}$ & $0.013 \mathrm{a}$ & $0.300 \mathrm{a}$ & $0.045 \mathrm{~b}$ & $2.774 \mathrm{a}$ & $0.012 \mathrm{a}$ \\
\hline Inorg. Mar. 15 & $0.457 \mathrm{~b}$ & $0.010 \mathrm{a}$ & $0.300 \mathrm{a}$ & $0.045 \mathrm{~b}$ & $2.174 \mathrm{ab}$ & $0.012 \mathrm{a}$ \\
\hline PL Oct. 15 & $0.115 \mathrm{c}$ & $0.015 \mathrm{a}$ & $0.316 \mathrm{a}$ & $0.087 \mathrm{a}$ & $0.797 \mathrm{~b}$ & $0.011 \mathrm{a}$ \\
\hline PL Nov. 20 & $0.100 \mathrm{c}$ & $0.015 \mathrm{a}$ & $0.316 \mathrm{a}$ & $0.087 \mathrm{a}$ & $0.793 \mathrm{~b}$ & $0.011 \mathrm{a}$ \\
\hline PL Dec. 30 & $0.064 \mathrm{c}$ & $0.014 \mathrm{a}$ & $0.316 \mathrm{a}$ & $0.086 \mathrm{a}$ & $0.811 \mathrm{~b}$ & $0.011 \mathrm{a}$ \\
\hline PL Feb. 10 & $0.082 \mathrm{c}$ & $0.010 \mathrm{a}$ & $0.308 \mathrm{a}$ & $0.074 \mathrm{ab}$ & $0.766 \mathrm{~b}$ & $0.011 \mathrm{a}$ \\
\hline PL Mar. 15 & $0.097 \mathrm{c}$ & $0.010 \mathrm{a}$ & $0.308 \mathrm{a}$ & $0.074 \mathrm{ab}$ & $0.737 \mathrm{~b}$ & $0.011 \mathrm{a}$ \\
\hline \multicolumn{7}{|c|}{ Orchardgrass } \\
\hline Inorg. Oct. 15 & $0.550 \mathrm{a}$ & $0.013 \mathrm{a}$ & $0.283 \mathrm{a}$ & $0.044 \mathrm{~b}$ & $2.650 \mathrm{a}$ & $0.012 \mathrm{a}$ \\
\hline Inorg. Mar. 15 & $0.514 \mathrm{a}$ & $0.011 \mathrm{a}$ & $0.283 \mathrm{a}$ & $0.043 \mathrm{~b}$ & $2.177 \mathrm{ab}$ & $0.012 \mathrm{a}$ \\
\hline PL Oct. 15 & $0.139 \mathrm{~b}$ & $0.018 \mathrm{a}$ & $0.314 \mathrm{a}$ & $0.089 \mathrm{a}$ & $0.741 \mathrm{~b}$ & $0.011 \mathrm{a}$ \\
\hline PL Nov. 20 & $0.121 \mathrm{bc}$ & $0.018 \mathrm{a}$ & $0.314 \mathrm{a}$ & $0.089 \mathrm{a}$ & $0.736 \mathrm{~b}$ & $0.011 \mathrm{a}$ \\
\hline PL Dec. 30 & $0.077 \mathrm{c}$ & $0.018 \mathrm{a}$ & $0.314 \mathrm{a}$ & $0.089 \mathrm{a}$ & $0.763 \mathrm{~b}$ & $0.011 \mathrm{a}$ \\
\hline PL Feb. 10 & $0.074 \mathrm{c}$ & $0.013 \mathrm{a}$ & $0.307 \mathrm{a}$ & $0.077 \mathrm{ab}$ & $0.762 \mathrm{~b}$ & $0.011 \mathrm{a}$ \\
\hline PL Mar. 15 & $0.075 \mathrm{c}$ & $0.013 \mathrm{a}$ & $0.306 \mathrm{a}$ & $0.075 \mathrm{ab}$ & $0.746 \mathrm{~b}$ & $0.011 \mathrm{a}$ \\
\hline \multicolumn{7}{|c|}{ Rye } \\
\hline Inorg. Oct. 15 & $0.548 \mathrm{a}$ & $0.047 \mathrm{a}$ & $0.265 \mathrm{a}$ & $0.056 \mathrm{~b}$ & $11.194 \mathrm{a}$ & $0.141 \mathrm{a}$ \\
\hline Inorg. Mar. 15 & $0.545 \mathrm{a}$ & $0.048 \mathrm{a}$ & $0.266 \mathrm{a}$ & $0.057 \mathrm{~b}$ & $10.116 \mathrm{a}$ & $0.141 \mathrm{a}$ \\
\hline PL Oct. 15 & $0.109 \mathrm{~b}$ & $0.061 \mathrm{a}$ & $0.348 \mathrm{a}$ & $0.180 \mathrm{a}$ & $0.493 \mathrm{~b}$ & 0.139 a \\
\hline PL Nov. 20 & $0.089 \mathrm{bc}$ & $0.062 \mathrm{a}$ & $0.349 \mathrm{a}$ & $0.180 \mathrm{a}$ & $0.486 \mathrm{~b}$ & $0.139 \mathrm{a}$ \\
\hline PL Dec. 30 & $0.051 \mathrm{c}$ & $0.063 \mathrm{a}$ & $0.349 \mathrm{a}$ & $0.180 \mathrm{a}$ & $0.558 \mathrm{~b}$ & $0.139 \mathrm{a}$ \\
\hline PL Feb. 10 & $0.046 \mathrm{c}$ & $0.061 \mathrm{a}$ & $0.346 \mathrm{a}$ & $0.178 \mathrm{a}$ & $0.549 \mathrm{~b}$ & $0.140 \mathrm{a}$ \\
\hline PL Mar. 15 & $0.063 \mathrm{bc}$ & $0.062 \mathrm{a}$ & $0.349 \mathrm{a}$ & $0.179 \mathrm{a}$ & $0.472 \mathrm{~b}$ & $0.144 \mathrm{a}$ \\
\hline
\end{tabular}

${ }^{a}$ Values represent means of 36-year simulations. Means within a column followed by the same letter do not differ significantly in Duncan's grouping ( $\alpha=$ 0.01 ).

${ }^{b}$ Inorg., inorganic fertilizer; PL, poultry litter.

greatly reduced in winter months, due to lower soil temperatures, decomposition processes are greatly slowed (Gregorich and Janzen 2000). Also, because erosion is generally controlled with pasture, the losses of $\mathrm{N}$ with the poultry litter are largely reduced. This is confirmed by having no 
Table 6. Effect of application date on $\mathrm{N}$ and $\mathrm{P}$ losses $\left(\mathrm{kg} \mathrm{ha}^{-1}\right)$ for the Coastal Plains soil region ${ }^{a}$

\begin{tabular}{lcccccc}
\hline $\begin{array}{l}\text { Fertilizer application } \\
\text { date }\end{array}$ & $\begin{array}{c}\text { Soluble } \\
\mathrm{N}\end{array}$ & $\begin{array}{c}\text { Soluble } \\
\mathrm{P}\end{array}$ & $\begin{array}{c}\text { Organic } \\
\mathrm{N}\end{array}$ & $\begin{array}{c}\text { Organic } \\
\mathrm{P}\end{array}$ & $\begin{array}{c}\text { Percolate } \\
\mathrm{N}\end{array}$ & $\begin{array}{c}\text { Percolate } \\
\text { Permudagrass }\end{array}$ \\
\hline Inorg. Oct. 15 & $0.580 \mathrm{a}$ & $0.004 \mathrm{a}$ & $0.007 \mathrm{~b}$ & $0.000 \mathrm{~b}$ & $9.130 \mathrm{a}$ & $0.101 \mathrm{a}$ \\
Inorg. Mar. 15 & $0.464 \mathrm{~b}$ & $0.003 \mathrm{a}$ & $0.007 \mathrm{~b}$ & $0.000 \mathrm{~b}$ & $8.060 \mathrm{a}$ & $0.101 \mathrm{a}$ \\
PL Oct. 15 & $0.066 \mathrm{c}$ & $0.008 \mathrm{a}$ & $0.017 \mathrm{a}$ & $0.007 \mathrm{a}$ & $0.694 \mathrm{~b}$ & $0.113 \mathrm{a}$ \\
PL Nov. 20 & $0.066 \mathrm{c}$ & $0.008 \mathrm{a}$ & $0.021 \mathrm{a}$ & $0.008 \mathrm{a}$ & $0.552 \mathrm{~b}$ & $0.113 \mathrm{a}$ \\
PL Dec. 30 & $0.042 \mathrm{~cd}$ & $0.008 \mathrm{a}$ & $0.021 \mathrm{a}$ & $0.009 \mathrm{a}$ & $0.334 \mathrm{~b}$ & $0.112 \mathrm{a}$ \\
PL Feb. 10 & $0.027 \mathrm{~d}$ & $0.006 \mathrm{a}$ & $0.018 \mathrm{a}$ & $0.005 \mathrm{ab}$ & $0.272 \mathrm{~b}$ & $0.112 \mathrm{a}$ \\
PL Mar. 15 & $0.019 \mathrm{~d}$ & $0.006 \mathrm{a}$ & $0.018 \mathrm{a}$ & $0.005 \mathrm{ab}$ & $0.259 \mathrm{~b}$ & $0.112 \mathrm{a}$ \\
& & & Tall fescue & & & \\
Inorg. Oct. 15 & $0.507 \mathrm{~b}$ & $0.006 \mathrm{a}$ & $0.020 \mathrm{a}$ & $0.001 \mathrm{~b}$ & $11.520 \mathrm{a}$ & $0.074 \mathrm{a}$ \\
Inorg. Mar. 15 & $0.586 \mathrm{a}$ & $0.004 \mathrm{a}$ & $0.020 \mathrm{a}$ & $0.001 \mathrm{~b}$ & $10.407 \mathrm{a}$ & $0.074 \mathrm{a}$ \\
PL Oct. 15 & $0.110 \mathrm{~cd}$ & $0.004 \mathrm{a}$ & $0.025 \mathrm{a}$ & $0.010 \mathrm{a}$ & $2.335 \mathrm{~b}$ & $0.067 \mathrm{a}$ \\
PL Nov. 20 & $0.107 \mathrm{~cd}$ & $0.004 \mathrm{a}$ & $0.025 \mathrm{a}$ & $0.010 \mathrm{a}$ & $2.272 \mathrm{~b}$ & $0.067 \mathrm{a}$ \\
PL Dec. 30 & $0.080 \mathrm{~d}$ & $0.004 \mathrm{a}$ & $0.025 \mathrm{a}$ & $0.010 \mathrm{a}$ & $2.250 \mathrm{~b}$ & $0.067 \mathrm{a}$ \\
PL Feb. 10 & $0.120 \mathrm{c}$ & $0.002 \mathrm{a}$ & $0.022 \mathrm{a}$ & $0.006 \mathrm{ab}$ & $2.105 \mathrm{~b}$ & $0.067 \mathrm{a}$ \\
PL Mar. 15 & $0.138 \mathrm{c}$ & $0.002 \mathrm{a}$ & $0.022 \mathrm{a}$ & $0.006 \mathrm{ab}$ & $2.034 \mathrm{~b}$ & $0.067 \mathrm{a}$ \\
& & & Rye & & & \\
Inorg. Oct. 15 & $0.562 \mathrm{a}$ & $0.036 \mathrm{a}$ & $0.024 \mathrm{a}$ & $0.011 \mathrm{~b}$ & $13.994 \mathrm{a}$ & $0.234 \mathrm{a}$ \\
Inorg. Mar. 15 & $0.587 \mathrm{a}$ & $0.038 \mathrm{a}$ & $0.024 \mathrm{a}$ & $0.011 \mathrm{~b}$ & $13.084 \mathrm{a}$ & $0.234 \mathrm{a}$ \\
PL Oct. 15 & $0.075 \mathrm{~b}$ & $0.046 \mathrm{a}$ & $0.082 \mathrm{a}$ & $0.081 \mathrm{a}$ & $0.887 \mathrm{~b}$ & $0.228 \mathrm{a}$ \\
PL Nov. 20 & $0.073 \mathrm{bc}$ & $0.046 \mathrm{a}$ & $0.082 \mathrm{a}$ & $0.081 \mathrm{a}$ & $0.772 \mathrm{~b}$ & $0.227 \mathrm{a}$ \\
PL Dec. 30 & $0.042 \mathrm{~cd}$ & $0.047 \mathrm{a}$ & $0.082 \mathrm{a}$ & $0.081 \mathrm{a}$ & $0.693 \mathrm{~b}$ & $0.227 \mathrm{a}$ \\
PL Feb. 10 & $0.026 \mathrm{~d}$ & $0.046 \mathrm{a}$ & $0.083 \mathrm{a}$ & $0.082 \mathrm{a}$ & $0.672 \mathrm{~b}$ & $0.232 \mathrm{a}$ \\
PL Mar. 15 & $0.037 \mathrm{~d}$ & $0.046 \mathrm{a}$ & $0.089 \mathrm{a}$ & $0.089 \mathrm{a}$ & $0.816 \mathrm{~b}$ & $0.247 \mathrm{a}$ \\
\hline
\end{tabular}

${ }^{a}$ Values represent means of 36-year simulations. Means within a column followed by the same letter do not differ significantly in Duncan's grouping ( $\alpha=$ $0.01)$.

${ }^{b}$ Inorg., inorganic fertilizer; PL, poultry litter.

significant difference with organic $\mathrm{N}$ losses for any of the treatments (except for bermudagrass in the Coastal Plains soil region) (Tables 4-8).

A significant reduction in $\mathrm{N}$ losses could also be noted for application of the chemical fertilizer on 15 March compared to application on 15 October in most cases, especially for applications to bermudagrass pasture. This likely resulted from increased exposure of inorganic $\mathrm{N}$ during the winter months, especially the warm season bermudagrass, which would not have active $\mathrm{N}$ uptake in the fall and early winter as does the cool season grasses. Confirmation of these differences can be observed with the probability figures of soluble $\mathrm{N}$ losses (Figures 2, 3, and 4), with large differences between the chemical fertilizer 
Table 7. Effect of application date on $\mathrm{N}$ and $\mathrm{P}$ losses $\left(\mathrm{kg} \mathrm{ha}^{-1}\right)$ for the Prairie soil region $^{a}$

Fertilizer application Soluble Soluble P Organic Organic Percolate Percolate date $^{b}$ $\mathrm{N}$ $\mathrm{N}$ $P$ $\mathrm{N}$ $P$

\begin{tabular}{lllllll}
\hline & \multicolumn{7}{c}{ Bermudagrass } \\
Inorg. Oct. 15 & $0.205 \mathrm{a}$ & $0.023 \mathrm{a}$ & $0.259 \mathrm{a}$ & $0.034 \mathrm{a}$ & $0.135 \mathrm{a}$ & $0.005 \mathrm{a}$ \\
Inorg. Mar. 15 & $0.178 \mathrm{~b}$ & $0.018 \mathrm{a}$ & $0.260 \mathrm{a}$ & $0.034 \mathrm{a}$ & $0.155 \mathrm{a}$ & $0.005 \mathrm{a}$ \\
PL Oct. 15 & $0.066 \mathrm{c}$ & $0.024 \mathrm{a}$ & $0.298 \mathrm{a}$ & $0.058 \mathrm{a}$ & $0.050 \mathrm{a}$ & $0.006 \mathrm{a}$ \\
PL Nov. 20 & $0.061 \mathrm{~cd}$ & $0.024 \mathrm{a}$ & $0.298 \mathrm{a}$ & $0.058 \mathrm{a}$ & $0.051 \mathrm{a}$ & $0.006 \mathrm{a}$ \\
PL Dec. 30 & $0.047 \mathrm{de}$ & $0.023 \mathrm{a}$ & $0.297 \mathrm{a}$ & $0.058 \mathrm{a}$ & $0.069 \mathrm{a}$ & $0.006 \mathrm{a}$ \\
PL Feb. 10 & $0.042 \mathrm{e}$ & $0.019 \mathrm{a}$ & $0.292 \mathrm{a}$ & $0.053 \mathrm{a}$ & $0.081 \mathrm{a}$ & $0.006 \mathrm{a}$ \\
PL Mar. 15 & $0.037 \mathrm{e}$ & $0.018 \mathrm{a}$ & $0.291 \mathrm{a}$ & $0.052 \mathrm{a}$ & $0.087 \mathrm{a}$ & $0.006 \mathrm{a}$ \\
& \multicolumn{7}{c}{ Tall fescue } & & & \\
Inorg. Oct. 15 & $0.199 \mathrm{a}$ & $0.021 \mathrm{a}$ & $0.543 \mathrm{a}$ & $0.075 \mathrm{a}$ & $0.000 \mathrm{a}$ & $0.000 \mathrm{a}$ \\
Inorg. Mar. 15 & $0.198 \mathrm{a}$ & $0.015 \mathrm{ab}$ & $0.543 \mathrm{a}$ & $0.074 \mathrm{a}$ & $0.000 \mathrm{a}$ & $0.000 \mathrm{a}$ \\
PL Oct. 15 & $0.064 \mathrm{~cd}$ & $0.017 \mathrm{ab}$ & $0.569 \mathrm{a}$ & $0.114 \mathrm{a}$ & $0.000 \mathrm{a}$ & $0.000 \mathrm{a}$ \\
PL Nov. 20 & $0.059 \mathrm{~d}$ & $0.017 \mathrm{ab}$ & $0.569 \mathrm{a}$ & $0.114 \mathrm{a}$ & $0.000 \mathrm{a}$ & $0.000 \mathrm{a}$ \\
PL Dec. 30 & $0.053 \mathrm{~d}$ & $0.016 \mathrm{ab}$ & $0.569 \mathrm{a}$ & $0.113 \mathrm{a}$ & $0.000 \mathrm{a}$ & $0.000 \mathrm{a}$ \\
PL Feb. 10 & $0.086 \mathrm{bc}$ & $0.010 \mathrm{~b}$ & $0.561 \mathrm{a}$ & $0.102 \mathrm{a}$ & $0.000 \mathrm{a}$ & $0.000 \mathrm{a}$ \\
PL Mar. 15 & $0.091 \mathrm{~b}$ & $0.010 \mathrm{~b}$ & $0.562 \mathrm{a}$ & $0.101 \mathrm{a}$ & $0.000 \mathrm{a}$ & $0.000 \mathrm{a}$ \\
& \multicolumn{7}{c}{ Rye } & & & & \\
Inorg. Oct. 15 & $0.190 \mathrm{a}$ & $0.062 \mathrm{a}$ & $0.753 \mathrm{a}$ & $0.122 \mathrm{~b}$ & $0.755 \mathrm{a}$ & $0.073 \mathrm{a}$ \\
Inorg. Mar. 15 & $0.193 \mathrm{a}$ & $0.065 \mathrm{a}$ & $0.753 \mathrm{a}$ & $0.123 \mathrm{~b}$ & $0.671 \mathrm{ab}$ & $0.073 \mathrm{a}$ \\
PL Oct. 15 & $0.070 \mathrm{~b}$ & $0.078 \mathrm{a}$ & $0.881 \mathrm{a}$ & $0.292 \mathrm{a}$ & $0.438 \mathrm{c}$ & $0.071 \mathrm{a}$ \\
PL Nov. 20 & $0.066 \mathrm{~b}$ & $0.078 \mathrm{a}$ & $0.881 \mathrm{a}$ & $0.292 \mathrm{a}$ & $0.484 \mathrm{bc}$ & $0.071 \mathrm{a}$ \\
PL Dec. 30 & $0.053 \mathrm{bc}$ & $0.079 \mathrm{a}$ & $0.881 \mathrm{a}$ & $0.293 \mathrm{a}$ & $0.585 \mathrm{abc}$ & $0.071 \mathrm{a}$ \\
PL Feb. 10 & $0.047 \mathrm{c}$ & $0.078 \mathrm{a}$ & $0.880 \mathrm{a}$ & $0.291 \mathrm{a}$ & $0.558 \mathrm{abc}$ & $0.072 \mathrm{a}$ \\
PL Mar. 15 & $0.059 \mathrm{bc}$ & $0.079 \mathrm{a}$ & $0.881 \mathrm{a}$ & $0.292 \mathrm{a}$ & $0.432 \mathrm{c}$ & $0.072 \mathrm{a}$ \\
\hline
\end{tabular}

${ }^{a}$ Values represent means of 36-year simulations. Means within a column followed by the same letter do not differ significantly in Duncan's grouping ( $\alpha=$ $0.01)$.

${ }^{b}$ Inorg., inorganic fertilizer; PL, poultry litter.

and the poultry litter applications rates being observed in all cases and a smaller but important difference observed between the application dates of the chemical fertilizer treatments. This difference in the chemical fertilizer resulting in large soluble $\mathrm{N}$ losses compared to the poultry litter application is consistent in all of the soil regions, regardless of whether they are within or outside of the poultry litter ban area of the state of Alabama.

Soluble N losses with poultry litter application were generally very low for all soil regions and in all pasture species, with the losses of $\mathrm{N}$ being predominantly less than the level of $0.2 \mathrm{~kg} \mathrm{ha}^{-1}$, as can be observed from the probability figures of soluble $\mathrm{N}$ losses (Figures 2, 3, and 4). 
Table 8. Effect of application date on $\mathrm{N}$ and $\mathrm{P}$ losses $\left(\mathrm{kg} \mathrm{ha}^{-1}\right)$ for the Piedmont Plateau region

\begin{tabular}{|c|c|c|c|c|c|c|}
\hline $\begin{array}{l}\text { Fertilizer application } \\
\text { date }^{b}\end{array}$ & $\begin{array}{l}\text { Soluble } \\
\mathrm{N}\end{array}$ & $\begin{array}{l}\text { Soluble } \\
\text { P }\end{array}$ & $\begin{array}{l}\text { Organic } \\
\qquad \mathrm{N}\end{array}$ & $\begin{array}{l}\text { Organic } \\
\text { P }\end{array}$ & $\begin{array}{l}\text { Percolate } \\
\text { N }\end{array}$ & $\begin{array}{c}\text { Percolate } \\
\text { P }\end{array}$ \\
\hline \multicolumn{7}{|c|}{ Bermudagrass } \\
\hline Inorg. Oct. 15 & $0.586 \mathrm{a}$ & $0.010 \mathrm{a}$ & $0.074 \mathrm{a}$ & $0.009 \mathrm{~b}$ & $9.208 \mathrm{a}$ & $0.084 \mathrm{a}$ \\
\hline Inorg. Mar. 15 & $0.457 \mathrm{~b}$ & $0.008 \mathrm{a}$ & $0.074 \mathrm{a}$ & $0.008 \mathrm{~b}$ & $7.982 \mathrm{a}$ & $0.084 \mathrm{a}$ \\
\hline PL Oct. 15 & $0.079 \mathrm{c}$ & $0.012 \mathrm{a}$ & $0.114 \mathrm{a}$ & $0.038 \mathrm{a}$ & $0.587 \mathrm{~b}$ & $0.088 \mathrm{a}$ \\
\hline PL Nov. 20 & $0.074 \mathrm{c}$ & $0.013 \mathrm{a}$ & $0.123 \mathrm{a}$ & $0.040 \mathrm{a}$ & $0.449 \mathrm{~b}$ & $0.086 \mathrm{a}$ \\
\hline PL Dec. 30 & $0.044 \mathrm{~cd}$ & $0.013 \mathrm{a}$ & $0.121 \mathrm{a}$ & $0.040 \mathrm{a}$ & $0.214 \mathrm{~b}$ & $0.086 \mathrm{a}$ \\
\hline PL Feb. 10 & $0.036 \mathrm{~d}$ & $0.009 \mathrm{a}$ & $0.115 \mathrm{a}$ & $0.033 \mathrm{a}$ & $0.185 \mathrm{~b}$ & $0.086 \mathrm{a}$ \\
\hline PL Mar. 15 & $0.027 \mathrm{~d}$ & $0.009 \mathrm{a}$ & $0.115 \mathrm{a}$ & $0.033 \mathrm{a}$ & $0.164 \mathrm{~b}$ & $0.086 \mathrm{a}$ \\
\hline \multicolumn{7}{|c|}{ Tall fescue } \\
\hline Inorg. Oct. 15 & $0.605 \mathrm{a}$ & $0.004 \mathrm{a}$ & $0.141 \mathrm{a}$ & $0.018 \mathrm{~b}$ & $12.465 \mathrm{a}$ & $0.052 \mathrm{a}$ \\
\hline Inorg. Mar. 15 & $0.528 \mathrm{~b}$ & $0.003 \mathrm{a}$ & $0.141 \mathrm{a}$ & $0.018 \mathrm{~b}$ & $11.357 \mathrm{a}$ & $0.052 \mathrm{a}$ \\
\hline PL Oct. 15 & $0.115 \mathrm{c}$ & $0.006 \mathrm{a}$ & $0.159 \mathrm{a}$ & $0.052 \mathrm{a}$ & $1.430 \mathrm{~b}$ & $0.043 \mathrm{a}$ \\
\hline PL Nov. 20 & $0.107 \mathrm{c}$ & $0.006 \mathrm{a}$ & $0.159 \mathrm{a}$ & $0.052 \mathrm{a}$ & $1.363 \mathrm{~b}$ & $0.043 \mathrm{a}$ \\
\hline PL Dec. 30 & $0.077 \mathrm{c}$ & $0.006 \mathrm{a}$ & $0.159 \mathrm{a}$ & $0.051 \mathrm{a}$ & $1.391 \mathrm{~b}$ & $0.043 \mathrm{a}$ \\
\hline PL Feb. 10 & $0.096 \mathrm{c}$ & $0.005 \mathrm{a}$ & $0.152 \mathrm{a}$ & $0.042 \mathrm{a}$ & $1.155 \mathrm{~b}$ & $0.043 \mathrm{a}$ \\
\hline PL Mar. 15 & $0.113 \mathrm{c}$ & $0.005 \mathrm{a}$ & $0.151 \mathrm{a}$ & $0.041 \mathrm{a}$ & $1.060 \mathrm{~b}$ & $0.043 \mathrm{a}$ \\
\hline \multicolumn{7}{|c|}{ Rye } \\
\hline Inorg. Oct. 15 & $0.593 \mathrm{a}$ & $0.044 \mathrm{a}$ & $0.132 \mathrm{a}$ & $0.032 \mathrm{~b}$ & $13.138 \mathrm{a}$ & $0.148 \mathrm{a}$ \\
\hline Inorg. Mar. 15 & $0.613 \mathrm{a}$ & $0.045 \mathrm{a}$ & $0.134 \mathrm{a}$ & $0.032 \mathrm{~b}$ & $11.807 \mathrm{a}$ & $0.148 \mathrm{a}$ \\
\hline PL Oct. 15 & $0.089 \mathrm{~b}$ & $0.056 \mathrm{a}$ & $0.218 \mathrm{a}$ & $0.141 \mathrm{a}$ & $0.500 \mathrm{~b}$ & $0.147 \mathrm{a}$ \\
\hline PL Nov. 20 & $0.078 \mathrm{bc}$ & $0.056 \mathrm{a}$ & $0.219 \mathrm{a}$ & $0.141 \mathrm{a}$ & $0.438 \mathrm{~b}$ & $0.146 \mathrm{a}$ \\
\hline PL Dec. 30 & $0.044 \mathrm{bc}$ & $0.057 \mathrm{a}$ & $0.219 \mathrm{a}$ & $0.142 \mathrm{a}$ & $0.389 \mathrm{~b}$ & $0.147 \mathrm{a}$ \\
\hline PL Feb. 10 & $0.032 \mathrm{c}$ & $0.056 \mathrm{a}$ & $0.219 \mathrm{a}$ & $0.140 \mathrm{a}$ & $0.384 \mathrm{~b}$ & $0.148 \mathrm{a}$ \\
\hline PL Mar. 15 & $0.050 \mathrm{bc}$ & $0.058 \mathrm{a}$ & $0.226 \mathrm{a}$ & $0.146 \mathrm{a}$ & $0.581 \mathrm{~b}$ & $0.158 \mathrm{a}$ \\
\hline
\end{tabular}

${ }^{a}$ Values represent means of 36-year simulations. Means within a column followed by the same letter do not differ significantly in Duncan's grouping ( $\alpha=$ 0.01 ).

${ }^{b}$ Inorg., inorganic fertilizer; PL, poultry litter.

However, some differences can be observed between the various poultry litter application treatments.

With the warm season bermudagrass, a significant reduction was noted for all locations in the amount of soluble $\mathrm{N}$ that was lost as the application date advanced from winter into spring. This improvement was for application dates on or after 30 December compared to earlier application dates at all locations (Tables 4-8). This was consistent with the yield and plant $\mathrm{N}$ uptake that was observed with the bermudagrass (Tables 1 and 2) and with the results observed with the chemical fertilizer application. With the warm season grass, soluble $\mathrm{N}$ losses could be reduced if the application of the litter is made closer to the time that plant 

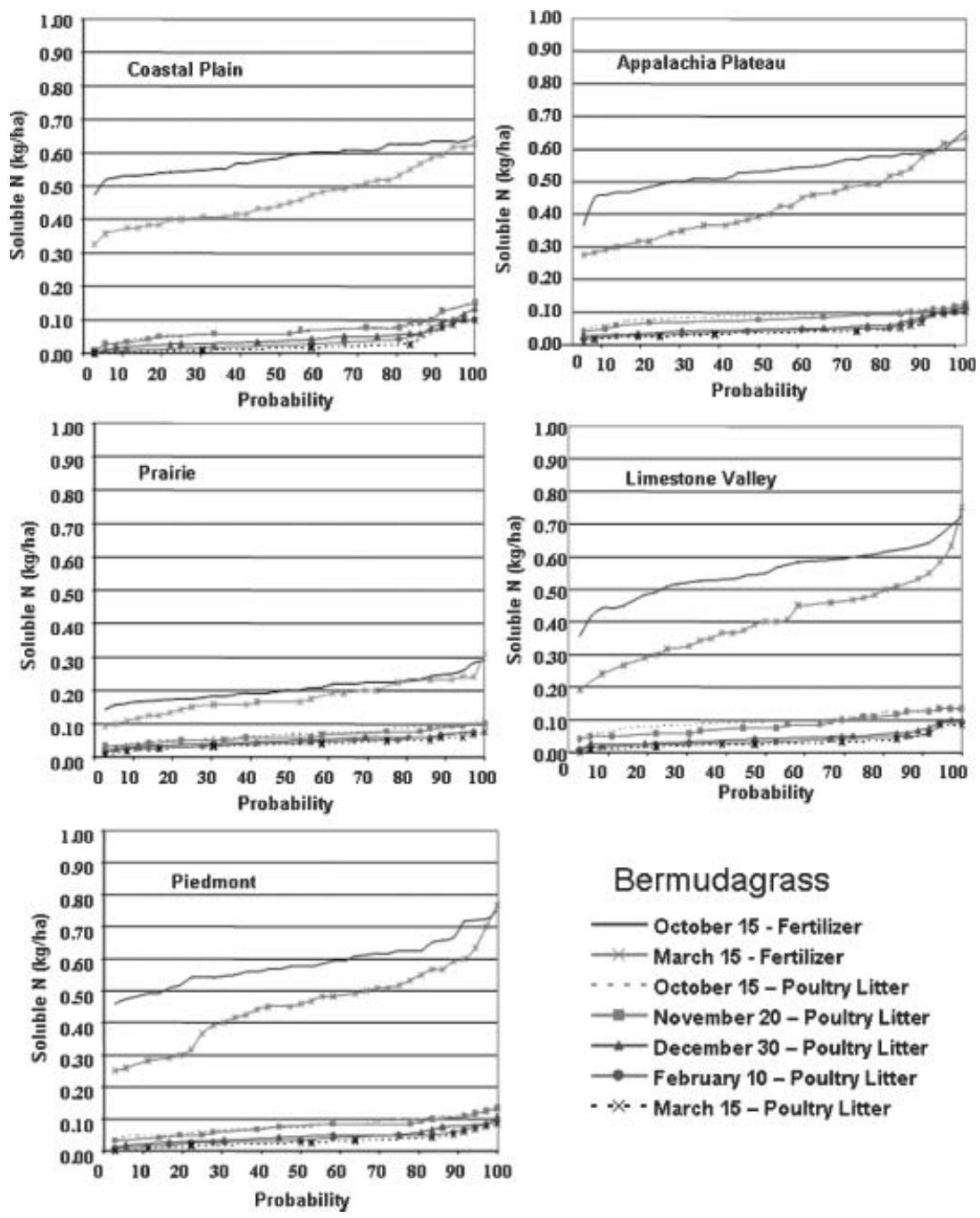

\section{Bermudagrass}

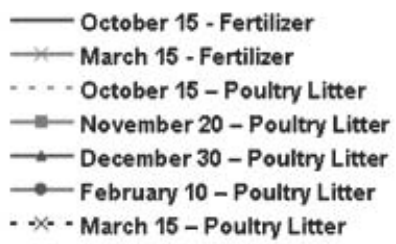

Figure 2. Cumulative probability of losses of soluble $\mathrm{N}$ for bermudagrass at each application date and for both the poultry litter and the chemical fertilizer treatments simulated over the 36 years of the study.

$\mathrm{N}$ uptake occurs with the grass. This is consistent with the reason for the winter poultry litter application ban to actively growing plants or within 30 days of planting (Mitchell 2001). However, no significant difference was noted for applications on or after 30 December with any of the soil regions examined.

Although losses of soluble $\mathrm{N}$ to runoff were increased with applications of poultry litter to bermudagrass compared to the other 

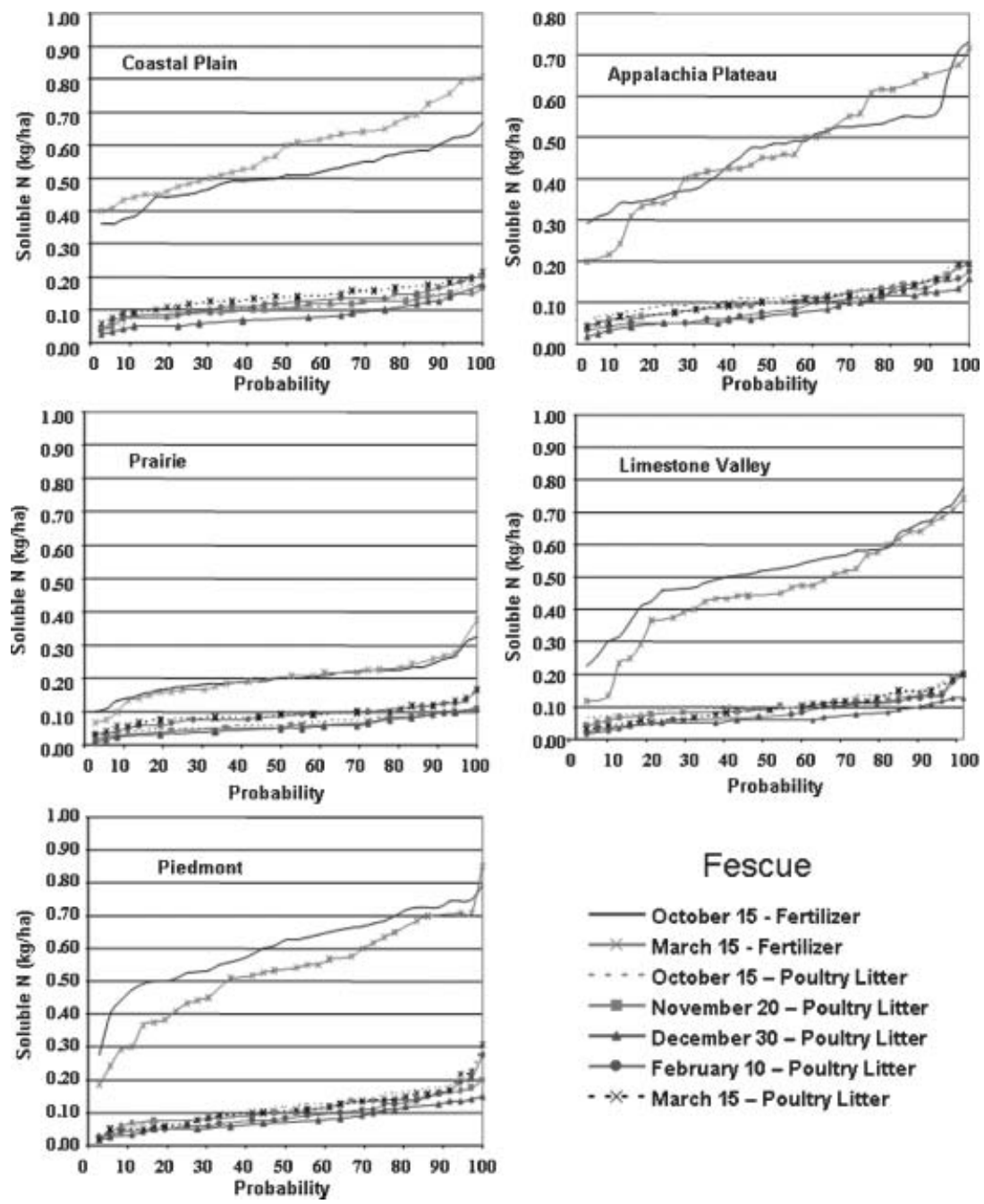

\section{Fescue}

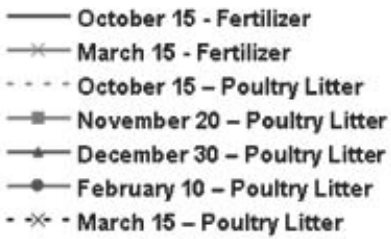

Figure 3. Cumulative probability of losses of soluble $\mathrm{N}$ for tall fescue at each application date and for both the poultry litter and the chemical fertilizer treatments simulated over the 36 years of the study.

pasture species, the losses of percolate $\mathrm{N}$ were decreased (Tables 4-8). This was likely because of the increased utilization of $\mathrm{N}$ in the bermudagrass compared to the other pasture species (Table 2). Although soluble $\mathrm{N}$ is lost in runoff while the grass is not growing during the cooler months, $\mathrm{N}$ movement through the soil can be utilized later when the plant begins to grow. With the increased growth and rooting depth of bermudagrass, a substantial reduction in $\mathrm{N}$ loss through 

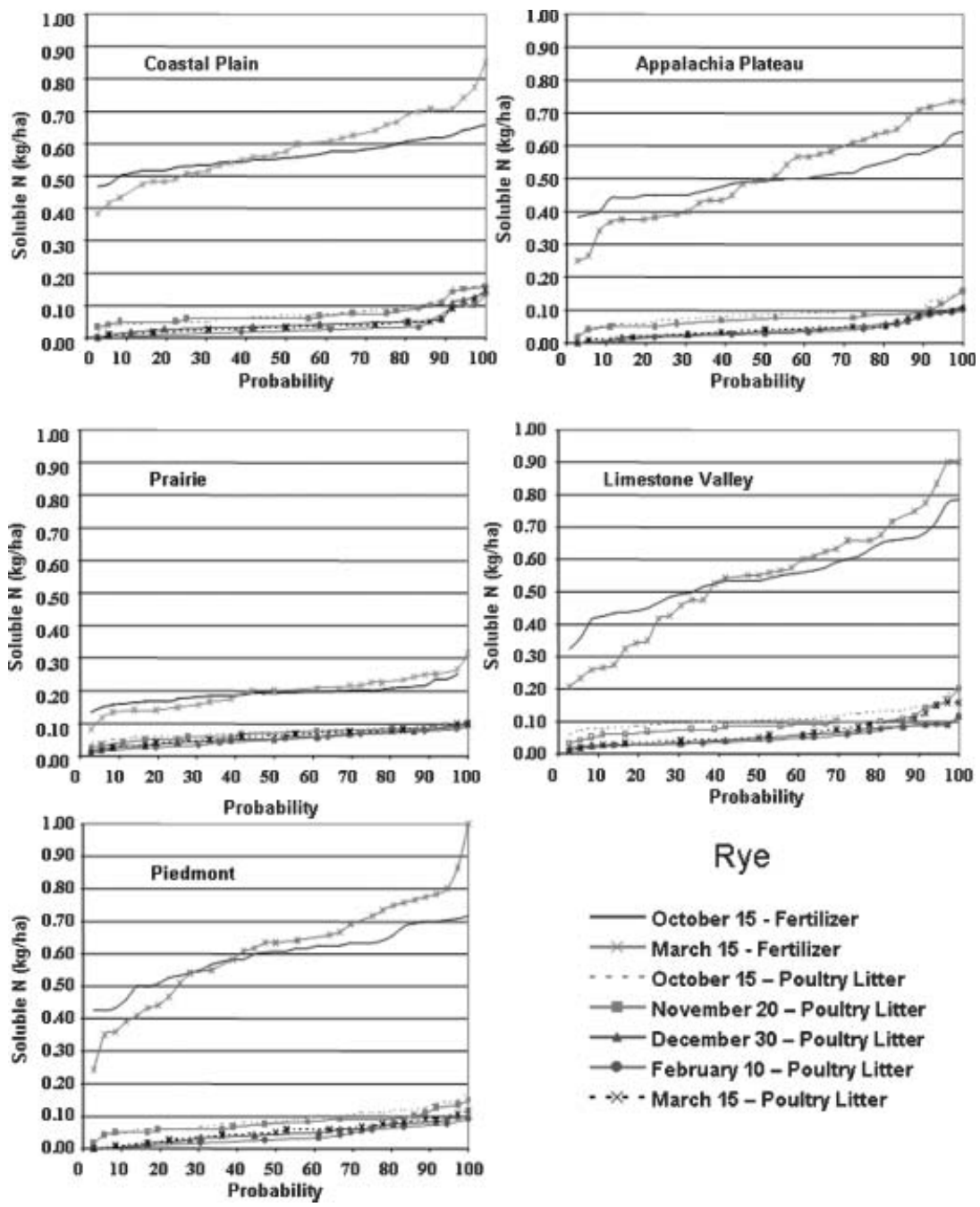

Rye

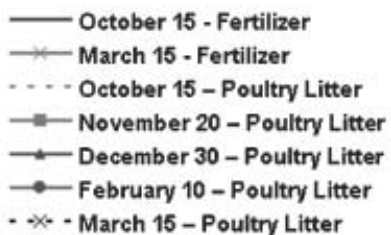

Figure 4. Cumulative probability of losses of soluble $\mathrm{N}$ for rye at each application date and for both the poultry litter and the chemical fertilizer treatments simulated over the 36 years of the study.

percolation was noted for all soil regions (except for rye in the prairie soil) (Tables 4-8).

Percolate $\mathrm{N}$ losses were lower with rye compared to tall fescue at all soil locations with the application of poultry litter, except for prairie soil (Tables 4-8). A small reduction in the level of percolate $\mathrm{N}$ loss in orchardgrass compared to tall fescue was also observed, but the difference cannot be clearly explained by yield and plant $\mathrm{N}$ uptake 

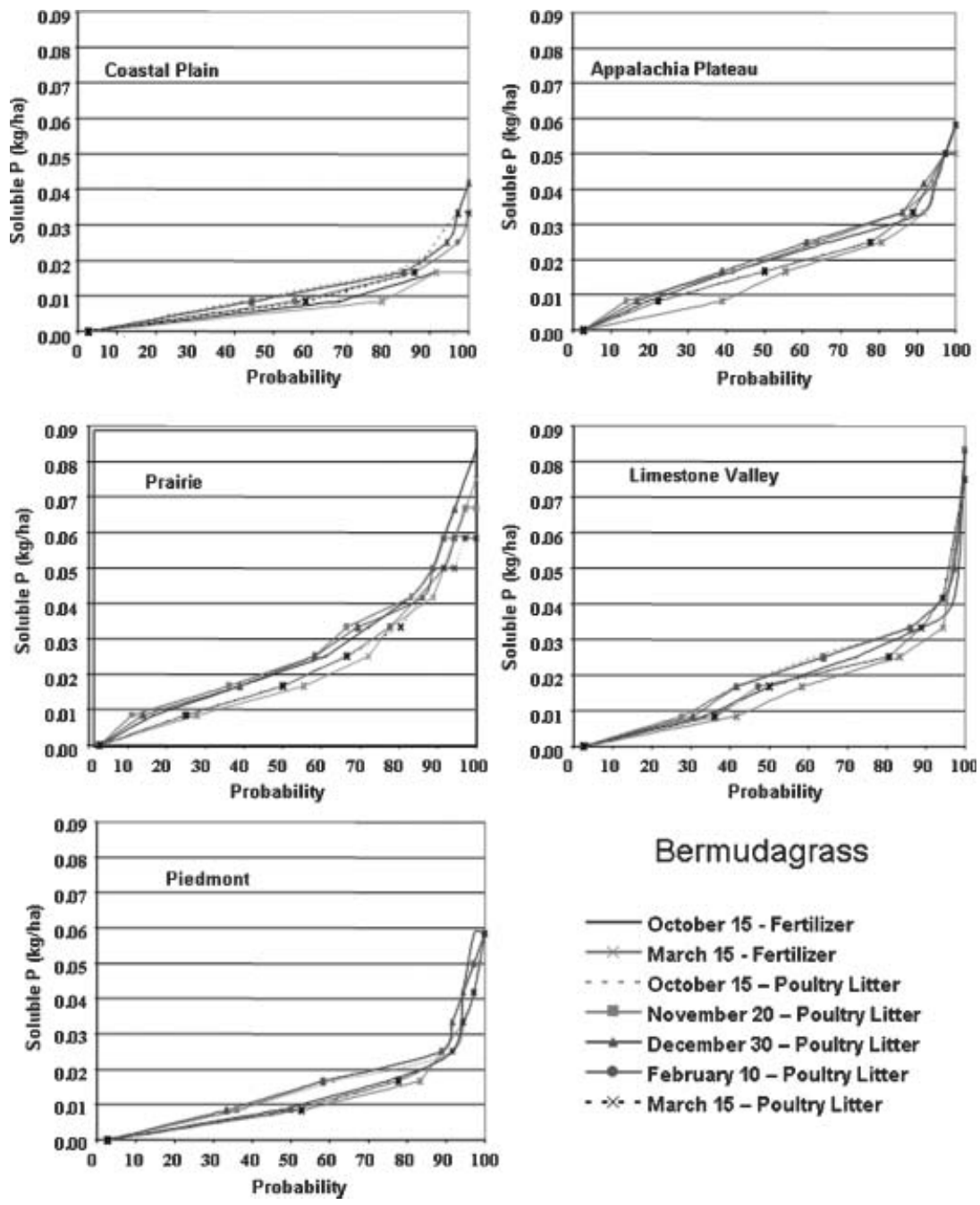

\section{Bermudagrass}

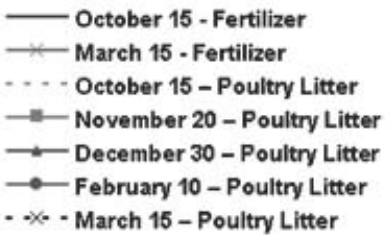

Figure 5. Cumulative probability of losses of soluble $\mathrm{P}$ for bermudagrass at each application date and for both the poultry litter and the chemical fertilizer treatments simulated over the 36 years of the study.

difference between the two plant species (Tables 1 and 2). No difference was observed for soluble $\mathrm{N}$ between these two species (Tables 4-8).

With the cool season grasses, there was no consistent significant difference in application dates (or consistent trend) for poultry litter for soluble $\mathrm{N}$ losses. This is confirmed by examining the probability figures, which indicated that there was very little and inconsistent differences between the poultry liter application dates over the expected losses of soluble $\mathrm{N}$ during the 36 years examined (Figures 2, 3, and 4). Likewise, 

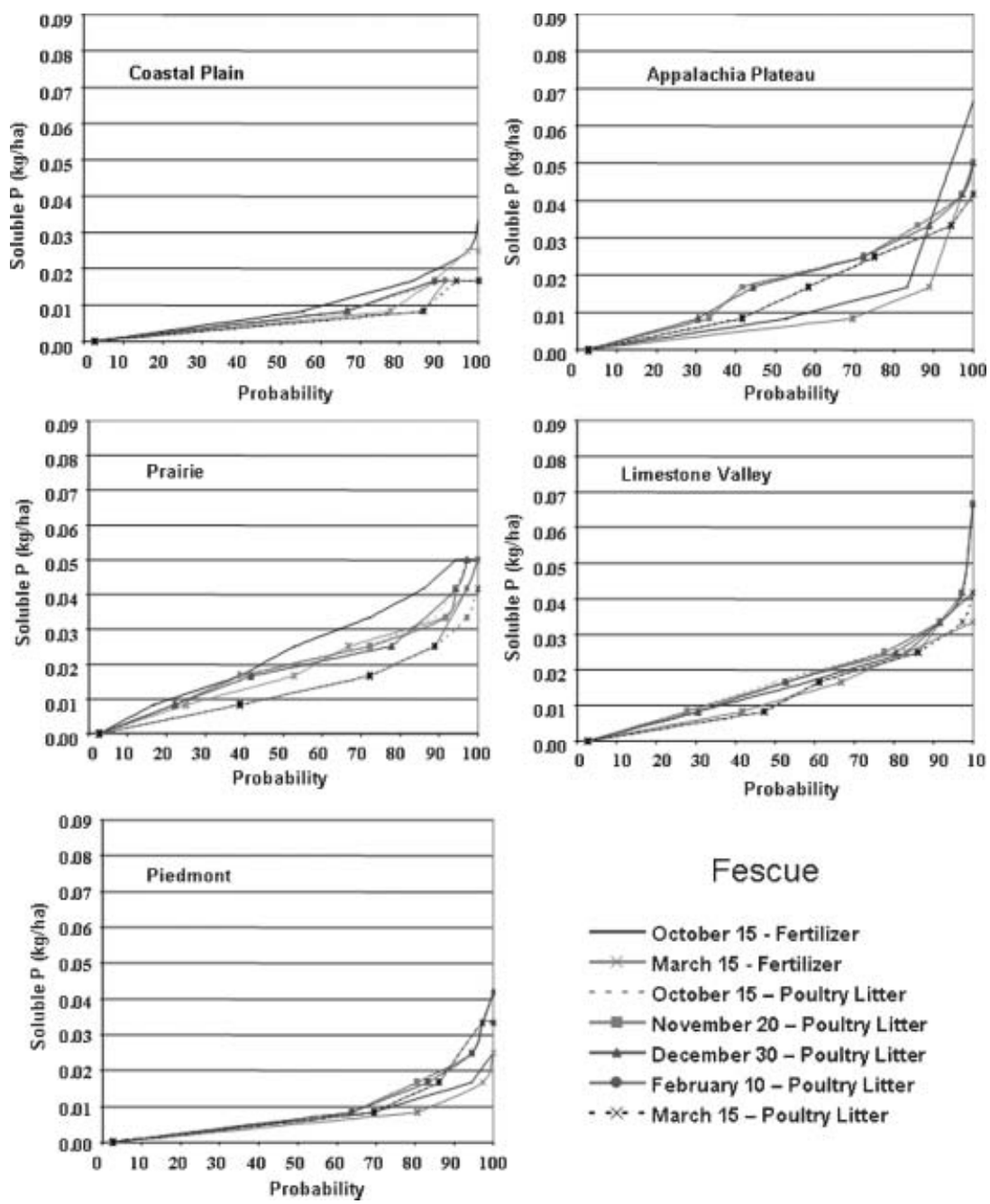

Figure 6. Cumulative probability of losses of soluble $\mathrm{P}$ for tall fescue at each application date and for both the poultry litter and the chemical fertilizer treatments simulated over the 36 years of the study.

there was no significant difference between the poultry litter application dates for percolate $\mathrm{N}$ (Tables 4-8). As was seen in the plant uptake of $\mathrm{N}$, there was no indication of a positive impact for application of the poultry litter during the time allowed by the ban compared to times when poultry litter application is banned. These findings were consistent for both the soil regions in north Alabama (within ban region) and south Alabama (below the poultry ban region). Again, this is consistent with findings of Sørensen and Thomsen (2005), who reported finding the same amount of 

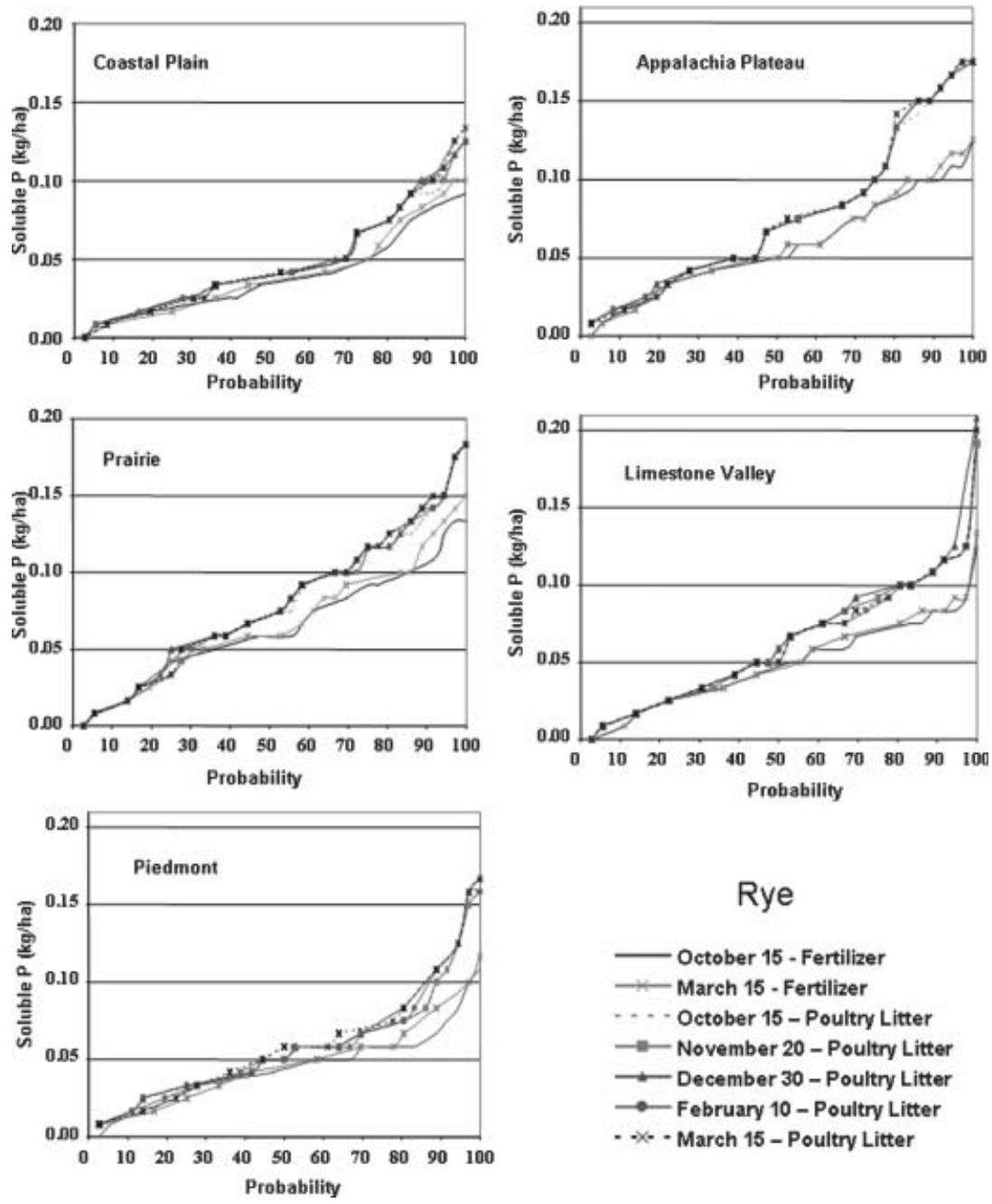

Figure 7. Cumulative probability of losses of soluble $\mathrm{P}$ for rye at each application date and for both the poultry litter and the chemical fertilizer treatments simulated over the 36 years of the study.

manure $\mathrm{N}$ lost irrespective of whether manure was applied in autumn or spring. Because the decomposition of the poultry litter (which releases the $\mathrm{N})$ would be promoted with the warmer climate found in south Alabama, there would be no justification for the poultry litter ban being limited to the northern portion of the state of Alabama.

With percolate $\mathrm{N}$, the sandy soil regions had higher levels of percolate $\mathrm{N}$ losses compared to the soil locations with soil textures having more clay. For example, the level of percolate $\mathrm{N}$ was much higher in the 
Appalachia Plateau soil compared to the Limestone Valley soil (Tables 4 8). Likewise, the Coastal Plains had higher percolate N losses. However, no meaningful difference could be observed between the sandy soils of the Appalachia Plateau in north Alabama (inside the ban area) and the Coastal Plains in south Alabama (outside the ban area). The results from the soluble $\mathrm{N}$ and percolate $\mathrm{N}$ indicates that the BMPs regarding the application of poultry manure may be improved by addressing differences in soil types rather than climatic plant growth characteristics.

\section{Soluble P}

The cumulative annual losses for soluble $\mathrm{P}$ in the runoff was very small relative to the application rate for all of the pasture species and at all of the soil locations, with a range of 0.002 to $0.084 \mathrm{~kg} \mathrm{Pha}^{-1}$ (Tables 4-8). Likewise, very small losses relative to the amount applied can be observed in the probability of soluble P loss figures (Figures 5, 6, and 7). The highest annual loss observed for soluble $\mathrm{P}$ was $0.21 \mathrm{~kg} \mathrm{ha}^{-1}(0.2 \%$ of the $\mathrm{P}$ applied each year) at the Limestone Valley soil location with rye, with most of the losses observed being some 10-fold lower than that observed at this location. Similarly, very small losses were observed for percolate $P$, with the highest average annual losses of $0.25 \mathrm{~kg} \mathrm{ha}^{-1}$ noted. This level of soluble P loss would obviously have no impact agronomically, because it was too small to impact plant growth or represent a measurable economic loss.

The low level of soluble $\mathrm{P}$ observed would be expected because $\mathrm{P}$ is held very tightly in soil and is lost in the form of soluble $\mathrm{P}$ only in very small amounts (Sharpley et al. 2003). However, because soluble P is usually the most limiting nutrient in freshwater environments, very small quantities can have an environmental impact, with concentrations as low as $0.02 \mu \mathrm{g} \mathrm{L}{ }^{-1}$, potentially accelerating eutrophication of surface waters (Sharpley et al. 2003). In this study, the $0.079 \mathrm{~kg} \mathrm{ha}^{-1}$ annual loss observed with the prairie soil would be equivalent to $0.2 \mu \mathrm{g} \mathrm{L}^{-1}$ over the year (calculated from average total runoff for the year); however, soluble $\mathrm{P}$ losses of $0.002 \mathrm{~kg} \mathrm{ha}^{-1}$ would be equivalent to $0.006 \mu \mathrm{g} \mathrm{L}^{-1}$ observed at the Coastal Plains location. Therefore, although some of the losses observed would be at a level of environmental importance, the predominance of the loss levels observed were less than the level of immediate environmental concern (Figures 5, 6, and 7).

There was no significant difference for soluble $\mathrm{P}$ loss observed between the application of $67 \mathrm{~kg} \mathrm{Pha}^{-1}$ as chemical fertilizer compared to $\mathrm{P}$ applied with the poultry litter. However, there was a significant reduction in organic $\mathrm{P}$ loss with application of chemical fertilizer $\mathrm{P}$ compared to poultry litter at all soil locations (Tables 4-8). This was likely because most of the $\mathrm{P}$ in the poultry litter was in the organic $\mathrm{P}$ 
form. A small trend was observed for the P fertilizer application to lower the soluble P losses compared to the poultry litter, which can be observed in some cases with the probability figures (especially in the Piedmont and Appalachia Plataea soil regions) (Figures 5, 6, and 7). This was likely because of the much smaller application of $P$ with the chemical fertilizer application compared to the poultry litter. This increased application rate could affect the difference in soluble P losses in both the short and long term. An increased loss over time would be expected as a result of the impact of soil P buildup over time. Mullins and Hajack (1997) showed that soil P buildup as predicted with EPIC was a very good predictor of the soil $\mathrm{P}$ reported in field studies with poultry litter application. However, because the soil level of $\mathrm{P}$ was reset every 10 years, the impact of soil $\mathrm{P}$ buildup did not significantly impact the soluble $\mathrm{P}$ losses in runoff. The buildup of soil $\mathrm{P}$ is undoubtedly an important issue that could impact surface water quality, but this issue is best addressed with tools such the P index (USDA NRCS 2001), which considers many factors contributing to runoff losses of $\mathrm{P}$ in addition to litter application timing.

As was observed with the soluble $\mathrm{N}$, there was no significant difference shown when averaged over all years for the poultry litter application dates in any of the soil regions or with any of the cool season or warm season pasture species studied (Tables 4-8). This was true for soil regions in north Alabama (within the ban area) as well as in south Alabama (outside the ban area). For example, in the Appalachia Plateau region, not only was there no significance difference between poultry litter application dates, but there was no distinguishable difference in soluble $\mathrm{P}$ losses between any of the poultry litter application dates observed in the cumulative probability figures for any of the plant species (Figures 5, 6, and 7).

Differences were observed between the plant species (Tables 4-8), but unlike with soluble $\mathrm{N}$, the warm season bermudagrass was not different from that observed with the cool season tall fescue and orchardgrass. In the case of soluble P losses, substantially higher losses were observed with rye compared to the other pasture species at all of the soil regions. This increased loss did not correspond to plant uptake of $\mathrm{P}$, which was consistently higher for rye compared to tall fescue but lower compared to bermudagrass at all locations (Tables 4-8). This indicates that the growing plant and plant $\mathrm{P}$ uptake was not responsible for this increased difference observed for $\mathrm{P}$ losses in rye. This was likely because soil $\mathrm{P}$ would not have been a limiting factor for plant uptake because of the level of $\mathrm{P}$ present in the soil in all cases (Adams, Mitchell, and Bryant 1994).

The increased level of soluble and organic $\mathrm{P}$ losses observed with rye was most likely due to the exposed ground during summer months. Rye is 
an annual plant species that required plowing and replanting each year. Most of the nutrients applied with poultry litter are in the organic form. During the winter months, they are tied up and are not susceptible to losses except by erosion. During the winter, all of the plant species areas gave good erosion control. However, during spring and summer, microbial activity starts to break down the poultry litter, and the nutrients are released into inorganic forms. During the summer, all of the pasture species maintain ground cover, except rye, which has exposed soil. The exposed soil surface would provide a maximum water/soil contact with the soil water moving across the soil surface in runoff events. This would also be consistent with the increased organic P losses observed with rye.

With percolate $\mathrm{P}$, no significant difference in application date was noted at any of the soil regions. However, as with percolate N, differences were observed for the sandy soil regions, which had higher levels of percolate $\mathrm{P}$ losses compared to the soil locations with more clay (Tables 4-8). This is consistent with findings of Kingery et al. (1994), who reported substantial percolation of $\mathrm{P}$ in a Hartsells fine sandy loam soil (an Appalachia Plateau soil). As was observed with percolate N, no meaningful difference could be observed between sandy soils of the Appalachia Plateau in north Alabama (inside the ban area) and the Coastal Plains soil in south Alabama (outside the ban area) (Tables 4-8). Although the percolation of $\mathrm{P}$ in sandy soil may be a problem (Kingery et al. 1994), there was no indication that the date of application or geographic location would impact percolate P losses.

As previously discussed, plant uptake of $\mathrm{P}$ was influenced more by plant yield than by the timing or amount of $\mathrm{P}$ applied, and the soluble $\mathrm{P}$ losses observed did not correspond to the level of plant $\mathrm{P}$ uptake reported in this study (Table 3). This indicates that factors other than plant $\mathrm{P}$ uptake during the growing season were the dominate regulators of the amount of soluble $\mathrm{P}$ lost in runoff. Also, the results clearly indicate that with soluble $\mathrm{P}$ losses to surface water, management components and cultural practices (such as planting and plowing) are more important than the $\mathrm{P}$ application corresponding to plant growth due to temperature and photoperiod. This would indicate that best management practices (BMP) such as are administered with the $\mathrm{P}$ index could be more important to regulate $\mathrm{P}$ losses to the environment.

\section{CONCLUSIONS}

A study was conducted to examine the potential impact of poultry litter application timing during winter months in north Alabama on nutrient movement important to water quality. The computer model WinEPIC 
was used to simulate poultry litter applications and chemical fertilizer application with both cool season and warm season grass pastures on the major soil regions of Alabama. The application times simulated were before, during, and after the period (15 November to 15 February) when manure application is limited in North Alabama. Surprisingly, little difference could be observed between the application dates for forage yield, both among poultry litter application dates and chemical fertilizer applications dates. With rye, a drop in yield could be observed with the 15 March application of poultry litter compared to the earlier (banned) application dates, likely as a result of $\mathrm{N}$ limitations of the poultry litter not having sufficient time to decompose to supply $\mathrm{N}$ before the peak growth period. With the warm season bermudagrass, plant $\mathrm{N}$ uptake was increased by waiting until spring to apply the litter in both the North Alabama and South Alabama soil type areas (Table 2).

With the cool season grasses, there was no indication that plant $\mathrm{N}$ uptake was positively impacted by application of the poultry litter during the time of actively growing plants, for soils both within and outside the ban area. With the warm season grass, soluble $\mathrm{N}$ losses could be reduced if the application of poultry litter was made after 30 December. With the cool season grasses, there was no significant difference in application dates for poultry litter for soluble $\mathrm{N}$ losses for any soil region, and no improvement could be noted for limiting applications in the ban area compared to the nonban area. No significant difference was observed for soluble P losses for application date for either warm season or cool season grass pastures. This indicates that factors other than plant $\mathrm{P}$ uptake during the growing season were the dominate regulators of the amount of soluble P lost in runoff. Also, the results would indicate that BMPs such as are administered with the $\mathrm{P}$ index are more important than plant growth factors in determining $\mathrm{N}$ and $\mathrm{P}$ losses to the environment in Alabama. Based on the results of this study, NRCS in Alabama could consider alterations of its recommendations for poultry litter application to both fully utilize poultry litter for crop production and to better protect the environment from nutrient losses.

\section{REFERENCES}

Adams, J. F., C. C. Mitchell, and H. H. Bryant. 1994. Soil test fertilizer recommendations for Alabama crops (Alabama Agriculture Experiment Station, Agronomy and Soils Department Series No. 178). Auburn, Ala.: Auburn University.

Alabama Agricultural Statistics Bulletin. 2004. Alabama Department of Agriculture and Industries and Alabama Agricultural Statistics Service. Available at http://www.aces.edu/dept/nass.

Ball, D. M., C. S. Hoveland, and G. D. Lacefield. 2002. Southern forages, 3rd ed. Norcross, Ga: Potash and Phosphate Institute. 
Correll, D. L. 1998. The role of phosphorus in the eutrophication of receiving waters: A review. Journal of Environmental Quality 27:261-266.

Daniel, T. C., A. N. Sharpley, and J. L. Lemunyon. 1998. Agricultural phosphorus and eutrophication: A symposium overview. Journal of Environmental Quality 27:251-257.

Edminsten, K. L., C. C. Mitchell Jr., C. W. Wood, and D. Delaney. 1992. Questions and answers about fertilizing with poultry litter (Alabama Cooperative Extension System Circular ANR-763). Available at Http://www.aces.edu/ department/grain/ANR763.htm.

Edwards, D. R., T. C. Daniel, J. F. Murdoch, and P. F. Vendrell. 1993. The Moore's Creek BMP effectiveness monitoring project (Pap. 932085). St. Joseph, Mich.: ASAE.

Gerik, T. J., W. L. Harman, J. R. Williams, L. Francis, J. Greiner, M. Magre, A. Meinardus, and E. Steglich. 2003. User's guide: CroPMan (crop production and management) model, version 3.2. Temple, Tex.: Blackland Research and Extension Center.

Gregorich, E. G., and H. H. Janzen. 2000. Decomposition. In Handbook of soil science, ed. M. E. Sumner. Boca Raton, Fl.: CRC Press.

Kellogg, R. L., and C. H. Lander. 1999. Trends in the potential for nutrient loadings from confined livestock operations. In The state of North America's private land. Washington, D.C.: USDA-NRCS, U.S. Government Printing Office. Available at http://www.nrcs.usda.gov/technical/land/pubs/ntrend.html (accessed December 2003).

Kingery, W. L., C. W. Wood, D. P. Delaney, J. C. Williams, and G. L. Mullins. 1994. Impact of long-term land application of broiler liter on environmental related soil properties. Journal of Environmental Quality 23:139-147.

McDowell, R. W., and A. N. Sharpley. 2001. Approximating phosphorus release from soils to surface runoff and subsurface drainage. Journal of Environmental Quality 30:508-520.

McFarland, A., and L. Hauck. 1999. Relating agricultural land uses to in-stream storm water quality. Journal of Environmental Quality 28:836-844.

Mitchell, C. 2001. Late fall and winter application of nutrients to cool-season forages in Alabama (S-01-01, Agronomy Series: Timely Information). Auburn, Ala.: Auburn University Agriculture and Natural Resources, Department of Agronomy and Soils.

Mitchell, C., and J. C. Meetze 1990. Soils of Alabama (Circular ANR-340). Available at http://www.aces.edu/department/grain/ANR340.htm (accessed May 2005).

Mullins, G. L., and B. F. Hajek 1997. Phosphorus accumulation and loss from Alabama soils receiving poultry litter (Alabama Agriculture Experiment Station Bulletin No.631). Auburn, Ala.: Auburn University.

Parry, R. 1998. Agricultural phosphorus and water quality: A U.S. Environmental Protection Agency perspective. Journal of Environmental Quality 27:258-261.

Pote, D. H., T. C. Daniel, A. N. Sharpley, P. A. Moore Jr., D. R. Edwards, and D. J. Nichols. 1996. Relating extractable soil phosphorus to phosphorus losses in runoff. Soil Science Society of America Journal 60:855-859.

SAS Institute, Inc. 1982. SAS users guide: Statistics. Cary, N.C.: SAS. 
Sharpley, A. N., T. Daniel, T. Sims, J. Lemunyon, R. Stevens, and R. Parry. 2003. Agricultural phosphorus and eutrophication (ARS-149). Springfield, Va.: U.S. Department of Agriculture, Agricultural Research Service, National Technical Information Service.

Sims, J. T., A. C. Edwards, O. F. Schoumans, and R. R. Simard. 2000. Integrating soil phosphorus testing into environmentally based agricultural management practices. Journal of Environmental Quality 29:60-71.

Sørensen, P., and I. K. Thomsen. 2005. Separation of pig slurry and plant utilization and loss of $15 \mathrm{~N}$-labeled slurry nitrogen. Soil Science Society of America Journal 69:1644-1651.

Torbert, H. A., T. C. Daniel, J. L. Lemunyon, and R. M. Jones. 2002. Relationship of soil test phosphorus to runoff phosphorus in calcareous soils. Journal of Environmental Quality 31:1380-1387.

Torbert, H. A., T. J. Gerik, W. L. Harman, J. R. Williams, and E. Steglich. 2005. Alabama CroPMan: A user friendly interface for crop production simulations. In Proceeding of the Southern Conservation Tillage Conference, 203-210 [CDROM]. Florence, S.C.: Pee Dee Research and Education Center.

USDA NRCS. 2001. Phosphorus index for Alabama: A planning tool to assess and manage $P$ movement (Agronomy Technical Note AL-72). Auburn, Ala.: USDA-NRCS.

USDA NRCS. 2005. General description for soil characterization data. Available at http://soils.usda.gov/survey/nscd/description.htm (accessed May 2005).

USDA and USEPA. 1999. Unified national strategy for animal finding operations. Available at http://cfpub.epa.gov/npdes/afo/ustrategy.cfm (accessed May 2005).

Wang, X., R. D. Harmel, J. R. Williams, and W. L. Harman. 2006. Evaluation of EPIC for assessing crop yield, runoff, sediment, and nutrient losses from watersheds with poultry liter fertilization. Transactions of the American Society of Agricultural and Biological Engineers (ASABE) 49:47-59.

Williams, J. R. 1995. The EPIC model. In Computer models of watershed hydrology, ed. V. P. Singh, 909-1000. Highlands Ranch, Colo.: Water Resources Publications. 